\title{
A Review of The Methanol Economy: The Fuel Cell Route
}

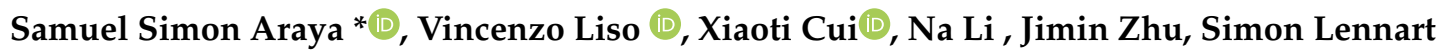 \\ Sahlin, Søren Højgaard Jensen, Mads Pagh Nielsen and Søren Knudsen Kæri
}

Department of Energy Technology, Aalborg University, 9220 Aalborg Øst, Denmark; vli@et.aau.dk (V.L.); xcu@et.aau.dk (X.C.); nal@et.aau.dk (N.L.); jzu@et.aau.dk (J.Z.); sls@et.aau.dk (S.L.S.); shje@et.aau.dk (S.H.J.); mpn@et.aau.dk (M.P.N.); skk@et.aau.dk (S.K.K.)

* Correspondence: ssa@et.aau.dk

Received: 21 December 2019; Accepted: 20 January 2020; Published: 29 January 2020

\begin{abstract}
This review presents methanol as a potential renewable alternative to fossil fuels in the fight against climate change. It explores the renewable ways of obtaining methanol and its use in efficient energy systems for a net zero-emission carbon cycle, with a special focus on fuel cells. It investigates the different parts of the carbon cycle from a methanol and fuel cell perspective. In recent years, the potential for a methanol economy has been shown and there has been significant technological advancement of its renewable production and utilization. Even though its full adoption will require further development, it can be produced from renewable electricity and biomass or $\mathrm{CO}_{2}$ capture and can be used in several industrial sectors, which make it an excellent liquid electrofuel for the transition to a sustainable economy. By converting $\mathrm{CO}_{2}$ into liquid fuels, the harmful effects of $\mathrm{CO}_{2}$ emissions from existing industries that still rely on fossil fuels are reduced. The methanol can then be used both in the energy sector and the chemical industry, and become an all-around substitute for petroleum. The scope of this review is to put together the different aspects of methanol as an energy carrier of the future, with particular focus on its renewable production and its use in high-temperature polymer electrolyte fuel cells (HT-PEMFCs) via methanol steam reforming.
\end{abstract}

Keywords: methanol; electrofuels; power-to-X; high temperature PEM; fuel cell; reforming

\section{Introduction}

The negative consequences of the continued use of fossil fuels on the planet are well documented and widely accepted, whereas the advantages of renewable energy sources are highly acclaimed [1-6]. Other than the existential consequence of keeping global warming below catastrophic limits, renewable sources, unlike fossil fuels, are neither limited resources nor located in certain areas of the globe, leading to geopolitical dependencies and conflicts.

The international energy agency (IEA) reported that in 2018 the global energy-related $\mathrm{CO}_{2}$ emissions rose to a record high $33.1 \mathrm{Gt} \mathrm{CO}_{2}$, of which more than $10 \mathrm{Gt}$ were from coal use in power generation, mainly in Asia [7]. The report also found that this increase was due to an increase in energy demand despite an increase in renewable sources of $7 \%$ in 2018 , which translated to $0.5 \%$ increase in $\mathrm{CO}_{2}$ emissions for every $1 \%$ gain in global economic output.

Therefore, a necessary transition from a fossil-based economy to one based on renewable sources is underway. For intance, in Denmark, a combination of increase in renewable power generation, mainly from wind (45\% in 2019, up from $38 \%$ in 2018) and phase-out of some coal power plants (from $17 \%$ in 2018 to $11 \%$ in 2019) has dropped the $\mathrm{CO}_{2}$ emission from electricity production to a record low $150 \mathrm{~g} \mathrm{CO}_{2} / \mathrm{kWh}_{\mathrm{el}}$ in 2019 from $199 \mathrm{~g} \mathrm{CO}_{2} / \mathrm{kWh}_{\mathrm{el}}$ in 2018 [8]. The drop is even more striking when compared to the emission levels of 2010 of $426 \mathrm{~g} \mathrm{CO}_{2} / \mathrm{kWh}_{\mathrm{el}}$ [8]. 
However, the major renewable energy sources, such as wind and solar are characterized by intermittency problems due to their dependency on weather conditions and time of day. To offset this, energy storage solutions are required in increasingly bigger scales if significant renewable penetration is to be achieved. Water electrolysis for hydrogen production from excess renewable electricity for later use at the time of higher demand is one of the most sought after options with very high capacity and fast response time for grid-balancing purposes $[9,10]$.

In this context, the produced hydrogen can also be used as long-term storage and then directly transported where it is needed, as a transportation fuel or for industrial applications. Alternatively, the hydrogen can be converted into the so called electrofuels according to the power-to-X concept, thereby storing the renewable electrical energy in the chemical bonds of gaseous or liquid fuels [11]. Methanol can be one of these carbon-neutral electrofuels when produced from hydrogen via electrolysis and $\mathrm{CO}_{2}$ from the atmosphere, biomass or from the exhaust of industrial processes [12-15].

While both hydrogen and methanol can be $\mathrm{CO}_{2}$ neutral if derived from renewable sources, methanol is easier to handle and a more direct substitute for oil in the chemical synthesis industry [16]. Moreover, being liquid at ambient temperature, methanol ties the habits and infrastructure of today's petroleum-based economy with the renewable energy systems of the future, where fuel cells and electrolyzers are expected to play a significant role. It can be converted back to hydrogen via the reforming process and the product gas mixture can either be directly used in high-temperature proton exchange membrane fuel cells (HT-PEMFC) or in low temperature PEM fuel cells after some purification, thereby enabling the hydrogen economy, too. Purified hydrogen can also be used in alkaline fuel cells and phosphoric acid fuel cells, which, however, suffer from sensitive electrolytes and lower power densities. A vision of the future based on methanol as an energy carrier for several applications is shown in Figure 1.

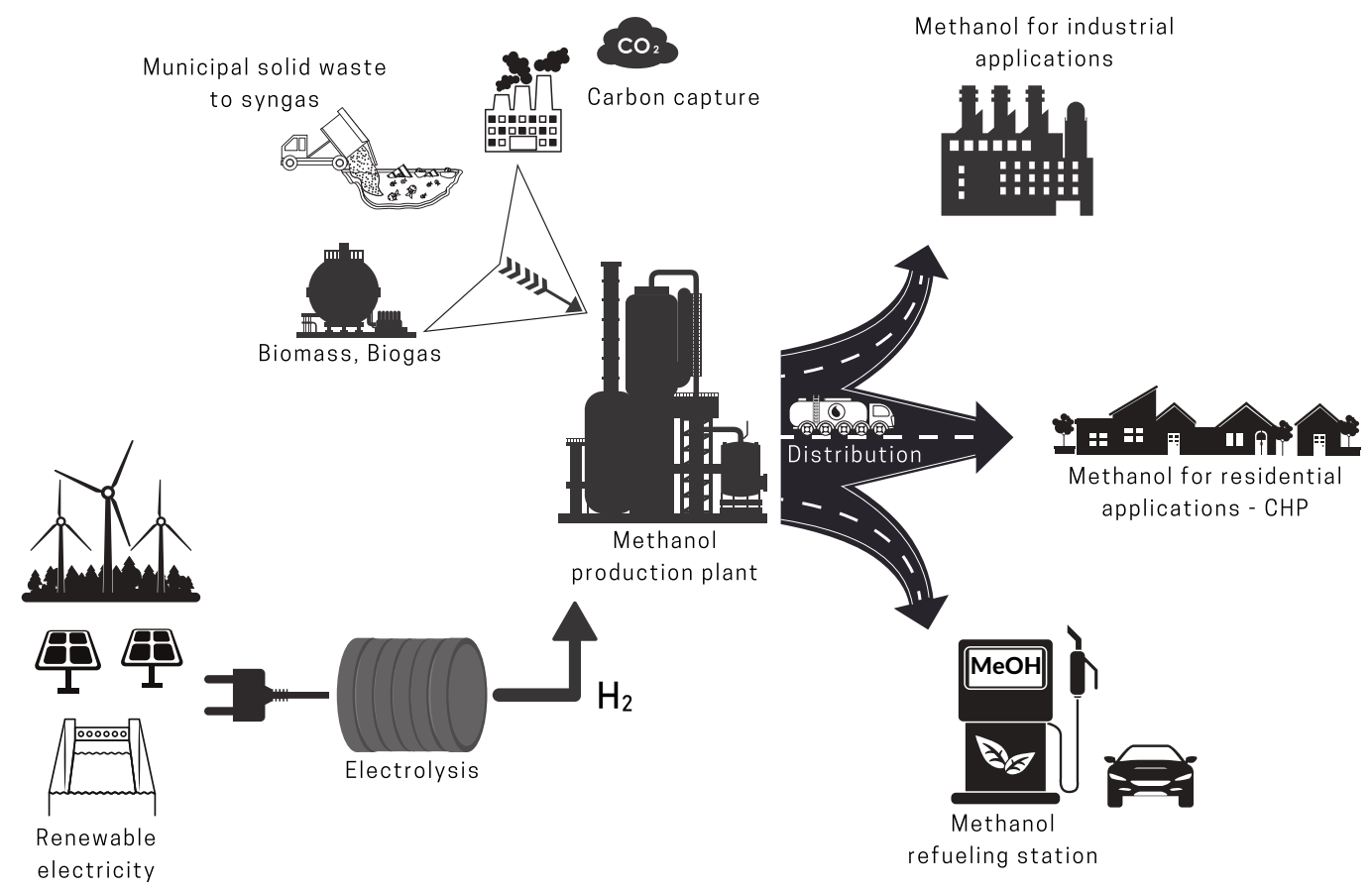

Figure 1. The renewable methanol economy.

Recently, the use of methanol in the energy sector is rapidly growing, reaching already $40 \%$ of the total methanol production, mainly due to China's policy to use methanol as a transportation fuel $[17,18]$. Therefore, this increased attractiveness in the energy sector and the possibility of using renewable methanol in the chemical industry, makes the "methanol economy" proposed by Nobel laureate George Andrew Olah an interesting prospect $[19,20]$. It not only provides an easy to handle 
long-term storage solution to enhance the renewable electricity penetration but also contributes to a more sustainable chemical industry by reducing its dependence on petroleum.

This paper focuses on methanol as a renewable energy carrier and a facilitator for the transition to a sustainable future. It summarizes the processes involved in producing the necessary hydrogen using renewable electricity, while also giving an overview of different sources for the $\mathrm{CO}_{2}$ used in methanol production. Finally, it discusses different applications in which methanol can be used competitively, both in terms of cost and efficiency. Particular attention is given to its use in high-temperature PEM fuel cells, also known as reformed methanol fuel cells (RMFC) when fed with hydrogen-rich gas via methanol steam reforming.

\section{Methanol Production}

Methanol, also known as wood alcohol, methyl alcohol or carbinol is a colorless, neutral, and polar liquid at ambient conditions, with boiling and freezing points of $64.6{ }^{\circ} \mathrm{C}$ and $-97.6{ }^{\circ} \mathrm{C}$, respectively [21]. It owes its discovery to Robert Boyle in 1661, who produced pure methanol through the rectification of crude wood vinegar over milk of lime [22]. It was known as heating fuel in the beginning of 1900 in Europe and was later used as fuel in automobiles in the 1920s [23]. Then, with the advent of the chemistry of one-carbon molecules, also know as $C_{1}$ chemistry, due to the successful large scale conversion of methanol and $\mathrm{CO}$ into important chemicals, methanol was mainly used in the chemical industry as a starting material or as a solvent [22-24].

Hence, the chemical industry has long been the main methanol consumer, dominated by the production of formaldehyde with 32\% of methanol production going to this purpose in 2011 [25]. Along with formaldehyde, other chemical derivatives can be produced from methanol, including, acetic acid/anhydride, the methyl ethers, methylamine, methyl chloride, the different methyl esters, and methanol compounds with sulfur and silicon, which are used as the secondary building blocks for the production of many value-added chemicals [23].

Consequently, the global methanol production has steadily increased in the past few decades from around 5 million metric tons in 1975 to around 110 million metric tons in 2018 [26]. Nowadays, methanol is already a key component of several everyday chemical products and its demand is estimated at around 100 million metric tons per year, increasing at an average annual growth rate of around 7\% [27] to an estimated 91.53 billion \$ global methanol market by 2026 [28].

\subsection{Traditional Methods}

The commercial methanol production has a long history of almost 100 years, since 1923 at the BASF's Leuna site [29]. Early developments have been extensively reviewed in the literature [29-31]. Nowadays, the production capacity for a large-scale methanol plant can reach up to more than 5000 metric tons per day [29] and mainly comprise of three processes: synthesis gas production, methanol synthesis and methanol distillation, as shown in Figure 2. The synthesis gas, which mainly contains $\mathrm{CO}, \mathrm{CO}_{2}, \mathrm{H}_{2}, \mathrm{H}_{2} \mathrm{O}$, some methane, inert gases and sulphur traces depending on the source, is predominantly produced by reforming of natural gas [32-34] or gasification of coal, with the latter especially used in China [22]. Other feedstocks for syngas production include liquefied petroleum gas, naphtha and biomass [33].

There is no doubt that syngas production is of great importance for a conventional methanol production both from technical and economical viewpoints. For instance, increasing the production capacity of a methanol plant requires a capacity expansion of the syngas production, where the main capital cost is associated with the reforming process [35]. Moreover, gas purification processes are usually involved in syngas production to avoid possible catalyst poisoning in the reforming process as well as the downstream methanol synthesis process. The reader is referred to the literature for the technical details of the different processes; reforming [33,35], coal gasification [36] and gas purification [37]. 


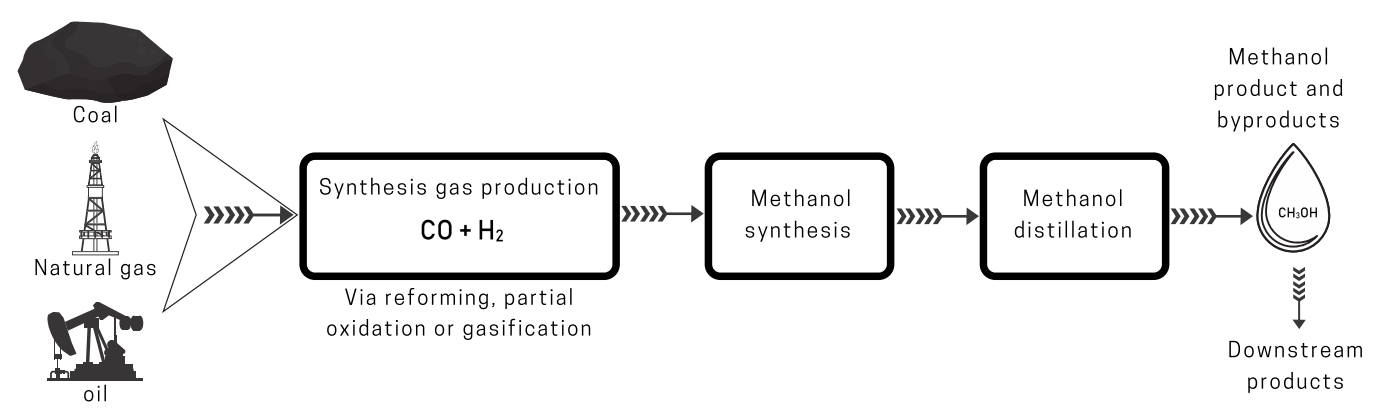

Figure 2. Schematic of the conventional methanol production process.

Nowadays, methanol is predominantly synthesized from the produced syngas using copper-based catalyst at operating pressures between $50-100$ bar and operating temperatures of $200-300^{\circ} \mathrm{C}$, and involves the hydrogenation of $\mathrm{CO}$ and $\mathrm{CO}_{2}$ and reverse water-gas shift (RWGS) reactions as shown below [38,39]:

$$
\begin{array}{ll}
\mathrm{CO}+2 \mathrm{H}_{2} \rightleftharpoons \mathrm{CH}_{3} \mathrm{OH} & \Delta H_{298 \mathrm{~K}}=-91 \mathrm{~kJ} / \mathrm{mol} \\
\mathrm{CO}_{2}+3 \mathrm{H}_{2} \rightleftharpoons \mathrm{CH}_{3} \mathrm{OH}+\mathrm{H}_{2} \mathrm{O} & \Delta H_{298 \mathrm{~K}}=-49 \mathrm{~kJ} / \mathrm{mol} \\
\mathrm{CO}_{2}+\mathrm{H}_{2} \rightleftharpoons \mathrm{CO}+\mathrm{H}_{2} \mathrm{O} & \Delta H_{298 \mathrm{~K}}=+41 \mathrm{~kJ} / \mathrm{mol}
\end{array}
$$

Due to the low one-pass conversion of $\mathrm{COx}\left(\mathrm{CO}\right.$ and $\left.\mathrm{CO}_{2}\right)$ to methanol of only about $5-15 \%$, the recycling of the unconverted syngas is usually necessary with a recycle ratio of between $2: 1$ and 5:1 [39]. A typical methanol synthesis loop along with the sucessive distillation step is shown in Figure 3. Before entering the methanol synthesis process, the composition of the synthesis gas is adjusted, for instance by adding $\mathrm{CO}_{2}$ according to the stoichiometric ratios in reactions 1 and 2, resulting in a stoichiometric number $\mathrm{SN}=\left(\mathrm{mol} \mathrm{H}_{2}-\mathrm{molCO}_{2}\right) /\left(\mathrm{mol} \mathrm{CO}+\mathrm{molCO}_{2}\right)$, which is usually around 2 or slightly higher for methanol synthesis [32]. The synthesis gas after the composition adjustment is called makeup gas (MUG). A MUG compressor (or multi-stage MUG compressor) is usually required to fulfill the pressure requirement for the methanol synthesis process, for example, the produced MUG with a pressure of 50 bar and the methanol converter operated at 80 bar. After the MUG compressor, the syngas is mixed with the recycled gas, which then enters the methanol converter.

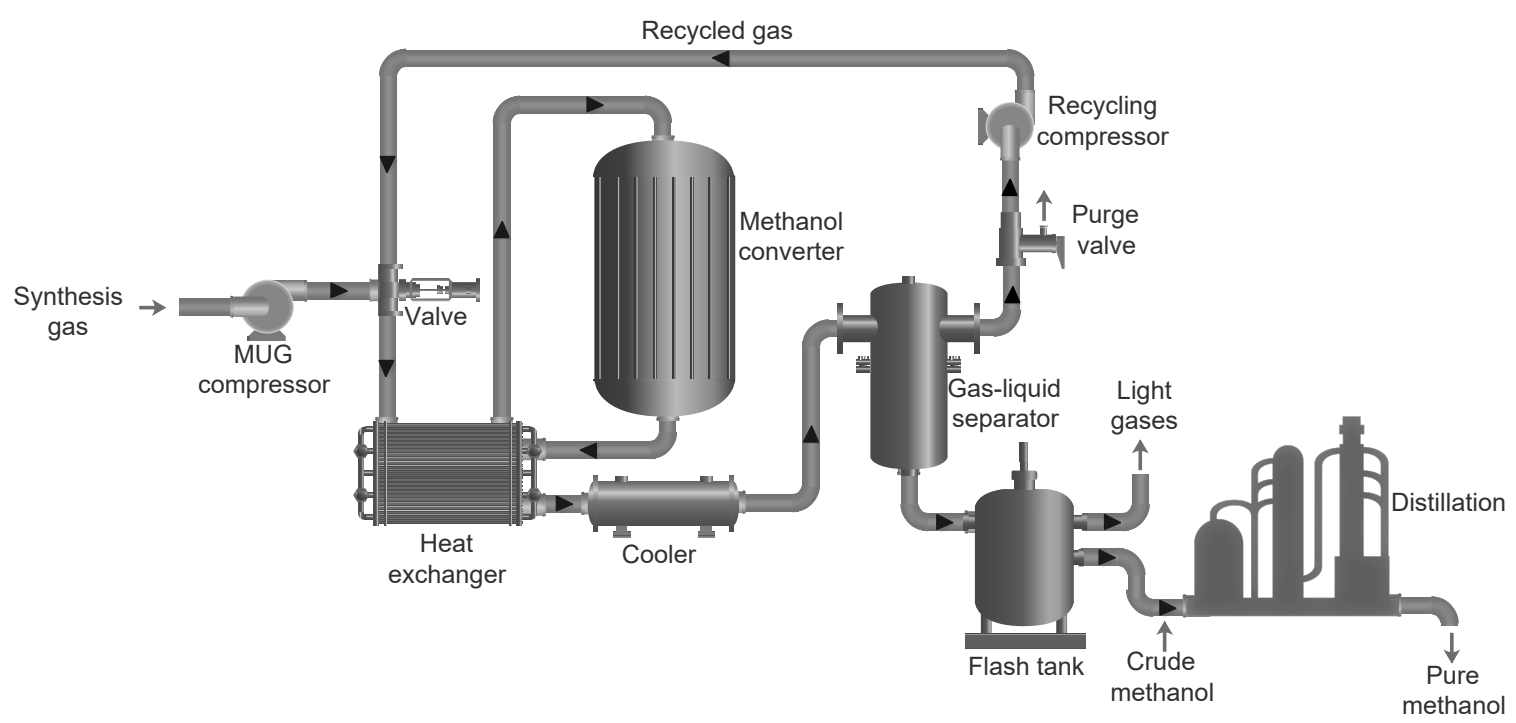

Figure 3. Schematic of a generic methanol synthesis process. 
There are mainly two types of methanol converters for commercial methanol production, namely multiple adiabatic catalyst beds with external cooling and internal cooling within one or more catalyst beds $[29,40]$. The latter is more favorable for industrial methanol production as it provides a more even temperature distribution and lower hot spot temperature in the catalyst bed, while the former is simpler and less expensive [29]. The commercial catalysts based on $\mathrm{CuO} / \mathrm{ZnO} / \mathrm{Al}_{2} \mathrm{O}_{3}$ are widely used in methanol production [38], since they provide both high activity and selectivity of typically above $99.5 \%$ [29]. Nonetheless, there is still room for improvement of the catalyst performance in terms of activity, selectivity, stability, and durability [41]. Catalyst deactivation usually occurs due to the poisoning by the impurities in the system and due to thermal effects, such as sintering of the copper particles. The representative converter designs and catalysts for methanol synthesis are thoroughly reviewed in the literature $[29,30,35,38,41]$.

The methanol produced in the methanol converter contains water, traces of higher alcohols such as ethanol, and dissolved synthesis gas [32,42]. Even though this crude methanol can be used directly for many applications, including producing Dimethyl ether (DME) [43] and biodiesel (when originated from biomass) [44], a distillation step is usually necessary to obtain methanol purity specifications required on the market, i.e, "AA" or chemical-grade methanol [42]. Distillation technologies are mature and 2 to 4 distillation columns are usually used in methanol plants. A three-column methanol distillation, i.e., a double-effect distillation scheme is commonly used in a large-scale methanol plant, where the light ends and dissolved gases are removed in the first column, and high-purity methanol is produced in the other two columns. This can save around 35\% energy demand compared to a two-column distillation scheme but has a higher investment cost [32]. An additional column could be added based on the three-column scheme to further recover the methanol from the heavy components, such as water and ethanol, especially when there are more byproducts in the raw methanol due to the catalyst deactivation in the methanol converter. Energy demand is one of the main concerns for the methanol distillation process and further optimizations focusing on the distillation process, such as multi-effect distillation [45,46] and heat pump assisted distillation [47], as well as the heat integration with other parts of the methanol plant are possible to lower the overall energy demand.

\subsection{Renewable Methanol}

The methanol economy envisioned in this paper goes hand in hand with the hydrogen economy and takes into account the increasing renewable penetration around the globe. Hence, producing methanol from surplus electricity via power-to-X processes is of paramount importance for a sustainable future. Unlike in the traditional methods, where 'black' methanol is produced from natural gas, coal and oil; renewable methanol, also known as 'green' methanol is produced from renewable $\mathrm{H}_{2}$ and $\mathrm{CO}_{2}$ sources with net zero $\mathrm{CO}_{2}$ emission, such as hydrogen from renewable electricity [48] and $\mathrm{CO}_{2}$ from biogas or the atmosphere [49]. When methanol is produced from waste and byproducts, which are only renewable to a degree, it is referred to as ' $g r e y$ ' methanol [50].

In the direct conversion of $\mathrm{CO}_{2}$ to methanol (CTM) process, the conventional syngas production in Figure 2 is replaced by the production and compression of $\mathrm{CO}_{2}$ (or $\mathrm{CO}_{2}$-rich feed gas) and $\mathrm{H}_{2}$, which can be achieved by relevant technologies, i.e., water electrolysis, $\mathrm{CO}_{2}$ capture and biogas production, in the methanol plant or from other sites. The process can be based on the mature technologies of syngas to methanol (STM) described previously with appropriate adjustments at all the stages of the synthesis process. For instance, since the enthalpy of reaction for reaction $2\left(\Delta H_{298 \mathrm{~K}}=-49 \mathrm{~kJ} / \mathrm{mol}\right)$ is less than that of reaction $1\left(\Delta H_{298 \mathrm{~K}}=-91 \mathrm{~kJ} / \mathrm{mol}\right)$, there is less requirement of heat removal for the CTM process, which indicates a possible lower operating temperature for the adiabatic converter and a larger diameter design of the reacting tube for the isothermal converter compared to those in the traditional STM process. Additionally, the tube-cooled reactor is also an option for this process [51]. Other novel reactors focusing on the in situ condensation and removal of the produced water and methanol, e.g., by using membrane reactors [39,52], sorption-enhanced [53,54] and natural convection [55] processes, are also reported at research level. 
However, hydrogenation of $\mathrm{CO}_{2}$ to methanol by reaction 2 introduces more water, which has a detrimental effect on the conventional Cu-based catalyst [56]. There has been increasing focus on the improvement and development of catalysts for this process since the early 1990s [22,57-61]. Some of the new generation commercial catalysts with high activity and stability for application in the CTM process, include, MK-151(Topsoe), MegaMax 800 (Clariant) and KATALCO 51-100 (Johnson Matthey) [30]. However, further investigations of current catalysts and development of novel catalysts are still required for a large-scale commercialization of CTM processes [62].

Compared to the STM process, the raw methanol produced in the CTM process contains more water and less byproducts [51]. Pontzen et al. [63] found 5 times lower byproduct content for the CTM process compared to STM, which opens the possibility to simplify the first distillation column and decrease the load for the other columns, in which the separation between methanol and the byproduct ethanol is the main concern. A simpler distillation system with one column or two columns was reported by Carbon Recycling International (CRI), where a stripper unit was connected to the overhead section of the first column to remove the dissolved $\mathrm{CO}_{2}$ and other light end impurities [51]. It should be noted that the load of the distillation system can also be lower if the product methanol is for fuel blending, where the separation between methanol and the small amount of ethanol is not necessary according to the different standards for fuel methanol blends, including the EN228 for European Gasoline and M5-M100 for the Chinese market [17].

Besides the pathway of direct $\mathrm{CO}_{2}$ conversion to methanol, a two-step process named CAMERE (carbon dioxide hydrogenation to methanol via reverse water gas shift (RWGS)) has also been reported [64]. The aim of the CAMERE process is to convert part of the $\mathrm{CO}_{2}$ in the feed gas to $\mathrm{CO}$ before the methanol synthesis process, and consequently decrease the detrimental effect of water on the catalyst for methanol synthesis. A pilot plant that uses this process was built by the Korean Institute of Science and Technology (KIST) with a methanol production of $75 \mathrm{~kg} /$ day, and an operating cost of around $300 \$ /$ ton methanol was estimated [65]. Anicic et al. [66] compared the two-step CAMERE process with the one-step CTM process, both with two reactors, and showed a slightly higher energy efficiency and lower cost for the direct one-step CTM process. Modeling studies on the application of membrane reactors for the CAMERE process were also reported in $[15,67]$.

Co-electrolysis using SOECs offer an interesting avenue towards higher $\mathrm{CO}_{2}$ to $\mathrm{MeOH}$ efficiencies [68-70]. $\mathrm{H}_{2}$ production using SOECs operated at 20 bar can reach about $96 \%$ conversion efficiency based on HHV [71]. Comparison with conversion efficiencies for AEC and PEMEC are provided in Table 1. Al-Kalbani et al. [72] modeled methanol production using high-temperature SOEC-based co-electrolysis of $\mathrm{H}_{2} \mathrm{O}$ and $\mathrm{CO}_{2}$. The production efficiency was found to be substantially higher for this system, than the production efficiency for a system based on water electrolysis and $\mathrm{CO}_{2}$ hydrogenation. Unfortunately, the conventional fuel electrode on SOECs contain Nickel, which catalyzes a part of the produced syngas into methane. Since a recycling ratio of $2-5$ is normally required in the methanol synthesis loop [39], this means $\mathrm{CH}_{4}$ accumulates in the loop, which in turn reduces the methanol production in the catalyst reactor. Furthermore, the $\mathrm{CH}_{4}$ formation in the SOEC fuel electrode is favored by pressure [73]. This challenges syngas production based on pressurized co-electrolysis using conventional SOEC fuel electrodes.

A small amount of sulphur can be added to the SOEC inlet gas which reduces the $\mathrm{CH}_{4}$ formation activity to almost zero without sacrificing too much of the electrochemical activity [74]. Unfortunately, Sulphur also increases the sintering activity of $\mathrm{Ni}$ [75], which accelerates electrode degradation. This decreases the SOEC lifetime, thereby making Sulphur addition a less attractive approach.

$\mathrm{Ni}$ serves two purposes in the SOEC fuel electrode. It is catalytically active for $\mathrm{H}_{2} \mathrm{O}$ and $\mathrm{CO}_{2}$ reduction, and it conducts electrons to the electrochemically active sites in the electrode. Substituting the $\mathrm{Ni}$ with $\mathrm{Cu}$ is one way to avoid $\mathrm{CH}_{4}$ formation. However, the sintering activity is higher for $\mathrm{Cu}$ than for $\mathrm{Ni}$, and the catalytic activity for $\mathrm{H}_{2} \mathrm{O}$ and $\mathrm{CO}_{2}$ reduction is higher for $\mathrm{Ni}$ than for $\mathrm{Cu}$ [76]. This leads to accelerated degradation and higher resistance if $\mathrm{Ni}$ is substituted with $\mathrm{Cu}$. Sufficiently low $\mathrm{Cu}$ sintering can be obtained if the SOEC operation temperature is reduced to $500{ }^{\circ} \mathrm{C}$ [76]. However 
such a low operation temperature results in high internal resistance, which implies a high system CAPEX [68].

Graves et al. recently demonstrated an interesting electrode where the current collector is substituted with $\mathrm{Sr}_{0.99} \mathrm{Fe}_{0.75} \mathrm{Mo}_{0.25} \mathrm{O}_{3-\delta}$ (SFM), and the catalytic activity is obtained with Pr-doped $\mathrm{CeO}_{2}(\mathrm{CPO})$ nano particles [77]. Such an electrode could enable pressurized co-electrolysis of $\mathrm{CO}_{2}$ and $\mathrm{H}_{2} \mathrm{O}$, without $\mathrm{Ni}$ or $\mathrm{Cu}$ sintering, and without $\mathrm{CH}_{4}$ formation.

\subsubsection{Technology Status and Prospects}

The CTM process is currently in the demonstration phase. A large-scale CTM pilot plant by CRI named after Nobel Prize laureate George Olah has been operating in Iceland since 2012 with a production capacity of 4000 tons per year of methanol, where the $\mathrm{CO}_{2}$ from the off-gas of a geothermal power plant and $\mathrm{H}_{2}$ from water electrolysis are converted to fuel grade methanol [51]. This is a way of exporting surplus renewable electricity in liquid form for an isolated country like Iceland with no electrical connections to neighboring countries but with abundant renewable electricity production, where the $\mathrm{H}_{2}$ production by water electrolysis benefits from the cheap electricity price [51].

Another pilot plant with a capacity of 100 tons per year located in Osaka was developed and built by Mitsui Chemicals and Research Institute of Innovative Technology for the Earth (RITE) in 2009 [30]. Early pilot-scale test plant with a production capacity of $50 \mathrm{~kg}$ methanol per day was also reported by RITE aiming at the development of efficient Cu-based catalyst for the CTM process [78,79]. Other pilot-scale plants include, a demonstration plant for a carbon-neutral synthetic fuel from carbon dioxide and hydrogen gases that uses a commercial catalyst from Johnson Matthey [80] and a CTM process by Lurgi/Air Liquide that uses commercial catalyst from Süd-Chemie (now Clariant) [63], where a stability test of 700 hours has been carried out. In the latter, the catalyst showed good activity and selectivity and a deactivation rate similar to that of the STM process. Other pilot plants were also reported in ongoing projects, such as the Carbon2Chem project in Germany, which is working on the production of fuel methanol from steel mill gases [81], and the Power2Met project in Denmark, which is focusing on the production of biomethanol from biogas [82].

With respect to the commercialization of green methanol, the production cost is still a major obstacle and dominated by the cost of $\mathrm{H}_{2}$ production [30]. However, there is potential to further decrease the production cost by using surplus electricity for water electrolysis, optimizing the electricity consumption according to the fluctuations of electricity price and reducing the cost of electrolyzers [83].

Moreover, the cost of the green methanol can also benefit from the efforts to lower cost of $\mathrm{CO}_{2}$ capture technology in the future as well as the implementation of carbon taxes in more countries. Klenert et al. [84] reported that carbon pricing is a necessary and effective economic tool for reducing GHG emissions and tackling climate change but is challenged by low political and public acceptability, which they recommend can be enhanced by carbon revenue recycling. Even though more countries are committing or pledging to implement carbon tax, at the moment carbon trading only covers $20 \%$ of global GHG emissions, out of which less than $5 \%$ are priced at levels consistent with reaching the temperature goals of the Paris Agreement [85].

The adoption of carbon pricing is thought to be particularly challenging to some emission-intensive and trade-exposed industries, which may require government subsidies [84]. However, emission-intensive industries are also ideal sites for methanol production as they provide high concentrations of $\mathrm{CO}_{2}$, which is easier and cheaper to sequester. Therefore, if incentivized through appropriate carbon pricing and trading schemes, they can contribute to tackling climate change not only by sequestrating their own emissions but also by replacing transportation fuels and raw materials for the chemical industry with methanol and its derivatives.

\subsubsection{Renewable $\mathrm{CO}_{2}$ Sources}

The renewable $\mathrm{CO}_{2}$ and $\mathrm{H}_{2}$ for the production of green methanol can be obtained from various local sources. The widely reported renewable $\mathrm{CO}_{2}$ sources are air [49] and biomass [14], 
with the technologies for air $\mathrm{CO}_{2}$ capture still at a research stage [49]. The biomass sources mainly include industrial and municipal waste, forestry and agriculture (including their residues) [14], where the biogenic $\mathrm{CO}_{2}$ is produced as a byproduct with different concentrations, e.g., $40 \mathrm{vol} \%$ of $\mathrm{CO}_{2}$ from a biogas plant and $85 \mathrm{vol} \% \mathrm{CO}_{2}$ from a bioethanol plant [86]. Clean and high purity of $\mathrm{CO}_{2}$ can be obtained by purification technologies, such as $\mathrm{H}_{2} \mathrm{~S}$ removal by physical and chemical absorption [87], and $\mathrm{CO}_{2}$ capture technologies, including amine-based post-combustion capture and cryogenic separation [49]. Additionally, since biogas contains high concentrations of $\mathrm{CH}_{4}$ and $\mathrm{CO}_{2}$, other processes, such as dry reforming [88] or bi-reforming [89], with the latter offering better catalyst stability, and co-electrolysis in solid oxide electrolyzer (SOEC) $[69,70,90]$ can be employed to directly produce syngas.

Since carbon-intensive industries play an important role in the global economy, $\mathrm{CO}_{2}$ capture and storage (CCS) technologies are identified by the International Energy Agency (IEA) as the only option for deep $\mathrm{CO}_{2}$ reduction for many industrial production sectors and equipping these industries with CCS was found to be the cheapest pathway for tackling global climate change to limit temperature rises to the $2{ }^{\circ} \mathrm{C}$ scenario [91]. It has been reported that despite the high cumulative energy demand for CCS, it ultimately results in a substantial lifetime GHG emission reduction of fossil fuel-based power plants, with up to $84 \%$ reduction at $90 \% \mathrm{CO}_{2}$ capture efficiency [92]. However, in the short term, due to their high energy-intensive nature, lack of clear business plans and an adequate $\mathrm{CO}_{2}$ tax system that penalizes the emitters, the real life use of CCS systems is very limited [93]. CCS systems consist of different separate processes: post-combustion, pre-combustion or oxy-fuel $\mathrm{CO}_{2}$ capture process, followed by a separation, transportation and storage processes, with the $\mathrm{CO}_{2}$ capture process accounting for around $70-80 \%$ of the total cost [93].

Even though there are no financially attractive CCS systems currently, due to the costs associated with the increased energy demand that lowers the overall energy production efficiency, utilization of the captured $\mathrm{CO}_{2}$ for economically productive applications could offset some of the costs [93]. Methanol production could be one such application, and when produced onsite, whereby $\mathrm{CO}_{2}$ storage and transportation are avoided, the process can become economically attractive. Pérez-Fortes et al. [94] performed a techno-economic and environmental assessment of methanol synthesis using captured $\mathrm{CO}_{2}$ as raw material. They found that the total $\mathrm{CO}_{2}$ demand is $1.46 \mathrm{t}_{\mathrm{CO}_{2}} / \mathrm{t}_{\text {methanol }}$ with a net potential for $\mathrm{CO}_{2}$ emissions reduction of $2.71 \mathrm{Mt}_{\mathrm{CO}_{2}}$ /year in Europe, assuming that the carbon capture and utilization (CCU) plants are built in Europe to meet methanol demand growth and the quantities that are currently imported. They also reported that the project is not financially viable due to the high cost of $\mathrm{H}_{2}$ and $\mathrm{CO}_{2}$.

However, with increased renewable electricity penetration and advancements in both electrolysis technology and methanol synthesis techniques, and appropriate carbon tax schemes, CCU for methanol synthesis could soon become profitable. Besides, the main carbon storage solution, namely, geological $\mathrm{CO}_{2}$ storage in unmineable coal beds, saline aquifers and in the deep ocean can result in potential leakage of the stored $\mathrm{CO}_{2}$ with hazardous consequences to the environment, including acidification, eutrophication, pollution and toxicity $[93,95]$.

\subsubsection{Renewable $\mathrm{H}_{2}$ Sources}

Another ingredient of the methanol synthesis process is $\mathrm{H}_{2}$, which is increasingly recognized as a clean and renewable energy carrier that is expected to play an important role in the fight against global warming and other environmental problems caused by fossil fuel combustion [96,97]. Majority of $\mathrm{H}_{2}$ is currently produced from natural gas via the reforming process. However, renewable ways of obtaining $\mathrm{H}_{2}$ are available, including water electrolysis via renewable electricity, such as solar photovoltaic (PV) and wind turbines, potentially offering grid balancing services as well [98-101]. Hydroelectric energy [102], ocean thermal $[103,104]$ and geothermal energy $[105,106]$ could also be utilized to produce hydrogen sustainably. Even though the cost-benefit analysis favors reforming over renewable sources [107], considering the current urgency to climate action, it is important to move 
towards renewable ways of producing hydrogen. Once produced, the hydrogen can then be stored as a compressed gas, as a cryogenic liquid, in metal hydrides or converted into electrofuels, including methanol and then utilized again to produce electrical energy and heat [108-111].

The history of water electrolysis stretches back to the first years of electricity discovery more than 200 years ago when Alessandro Volta invented the voltaic pile in 1800 showing that electricity can be produced by chemical reactions, and few weeks later William Nicholson and Anthony Carlisle used it for electrolytic splitting of water [112]. In 1888, Dmitry Lachinov developed a technique for industrial water electrolysis, which resulted in more than 400 industrial water electrolyzers in operation already by the year 1902, and development of the technology continued, mainly driven by the industrial hydrogen and oxygen demand, with the first large plant with a capacity of $10,000 \mathrm{Nm}^{3} \mathrm{H}_{2} /$ h established in $1939[112,113]$.

In water electrolysis, electricity (direct current (DC)) is used to split water into its components, $\mathrm{H}_{2}$ and $\mathrm{O}_{2}$ according to the following overall reaction:

$$
\mathrm{H}_{2} \mathrm{O}(\mathrm{l}) \stackrel{\text { electricity }}{\longrightarrow} \mathrm{H}_{2}(\mathrm{~g})+\frac{1}{2} \mathrm{O}_{2}(\mathrm{~g}) \text {. }
$$

The reaction happens electrochemically on two electrodes separated by an electrolyte, where the oxygen evolution half cell reaction (OER) takes place on the anode side and hydrogen evolution half cell reaction (HER) on the cathode side.

The most common types of electrolyzer cells, based on the electrolyte materials they employ and their operating parameters are: solid oxide electrolysis cell (SOEC), alkaline water electrolysis cells (AEC), and polymer electrolyte membrane electrolysis cells (PEMEC) [114]. SOEC is the most efficient of the three cell types as the electrical demand decreases with increasing operating temperature due to favorable thermodynamics [115]. However, the high operating temperature also means more stringent material requirements and long-term stability issues [116,117]. As already mentioned, SOEC can also be use for co-electrolysis of steam and $\mathrm{CO}_{2}$ to produce syngas [90].

The alkaline water electrolyzer is the most mature technology among the three with some advantages in structure and cost and it is suitable for large-scale hydrogen production. It uses a liquid electolyte of $20-40 \mathrm{wt}$. \% concentration of either $\mathrm{NaOH}$ or $\mathrm{KOH}$ and operates between $70-90{ }^{\circ} \mathrm{C}$ at below $3 \mathrm{MPa}$ [115]. However, disadvantages such as higher energy consumption, lower efficiency, strongly corrosive environment, and limited capability to work at high pressure due to gas cross-over restrict its further development $[118,119]$.

Compared to the other types of water electrolyzers, PEM water electrolyzer stands out among other things for its higher hydrogen production rate, higher current density, higher gas purity (above 99.99\%), low gas permeability, wide dynamic operation range, compact design, and rapid response [120-123]. AEC and SOEC based systems combined with purification can achieve similar high gas purity, but AEC still suffers from the above mentioned limitation and SOEC requires further development. Therefore, PEM water electrolysis is considered a promising technology to generate hydrogen from renewable and fluctuating electricity. However, the corrosive acid environment at a $\mathrm{pH}$ of around 2 and high applied voltage, especially at high current densities require highly resistant and costly materials, namely noble metals, such as $\mathrm{Pt}$, Ir, and $\mathrm{Ru}$ for the catalyst, and titanium for the current collectors and separator plates [120]. These metals are scarce on the Earth's crust, especially the noble catalysts, with $\mathrm{Ir}$ or $\mathrm{IrO}_{2}$, which are currently the catalysts of choice for the anode side OER, being the scarcest of them. Prices for these metals are bound to further increase with the commercialization of electrolyzers, fuel cells, and other electrochemical devices. Hence, research on reducing the catalyst loading and using new materials is ongoing to reduce the cost of PEM electrolyzers [120,124,125].

Water photoelectrolysis, also known as Photoelectrochemical (PEC) water splitting, is another renewable way of producing hydrogen, which employs solar energy to decompose water [126-128]. In order to better absorb the sunlight radiation for efficient hydrogen production, studies on new semiconductor materials with the properties of super stability, high photocatalytic activity, and 
visible light absorption are crucial [127]. At the moment, it is still challenging to balance the cost of the materials and infrastructure for large-scale photoelectrolyzers and the hydrogen production rate of the system. Therefore, more effort is needed to reach a reasonable solar-to-hydrogen efficiency and achieve practical and economical hydrogen production with this process [128].

\section{Methanol Use}

Methanol is already one of the most important and widely traded chemical commodities, and its demand is growing rapidly with a compound annual growth rate (CAGR) of $6 \%$ between 2014 and 2019 [17]. This is mainly due to its versatility and the numerous industrial sectors it serves. As shown in Figure 4, it not only can be produced from various feedstock, but can also be used in several applications. In the following sections, an overview of its use in the chemical industry and the energy sector is given. Even though it is still extensively used in the chemical industry, this review focuses on its use in the energy sector, especially in fuel cells, as it investigates methanol as a renewable energy carrier.

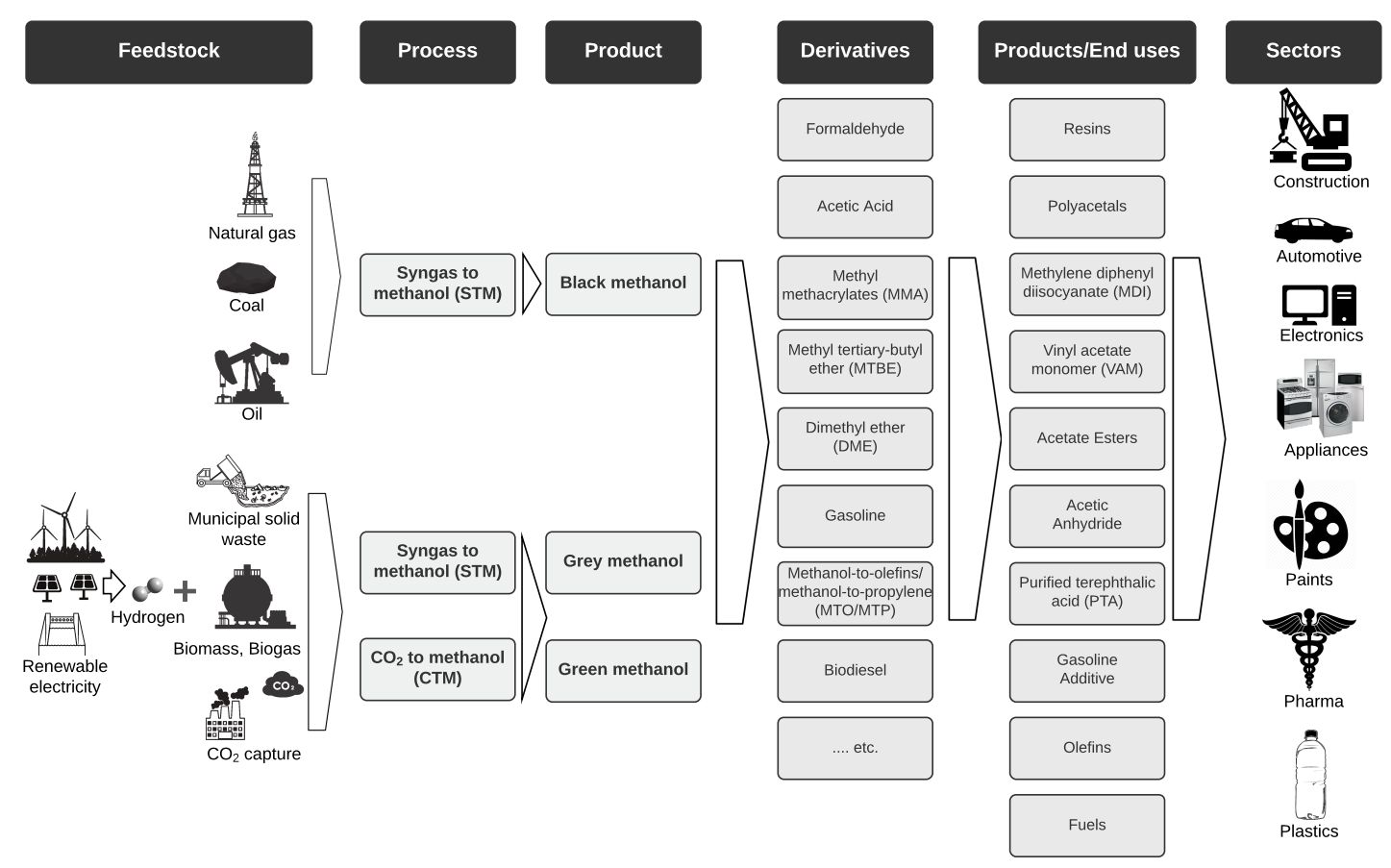

Figure 4. The methanol value chain. Adapted from $[30,129]$.

\subsection{Methanol in The Chemical Industry}

The chemical industry has long relied on fossil fuels for its processes. However, a transition driven by climate goals is underway to make the chemical industry more sustainable, both its raw materials and energy demand. Even though methanol is predominantly produced from fossil sources at the moment, the plethora of methanol chemical derivatives and products pave the way for a green methanol-based chemical industry. The fact that it is already one of the most important chemical commodities also makes it an ideal candidate for this transition and can help integrate fossil raw materials and biomass value chains [30].

For instance, lower $\mathrm{C}_{2}-\mathrm{C}_{4}$ olefins (ethylene and propylene) that are normally produced from crude oil and are the most important monomers for further petrolchemical and chemical synthesis processes can be produced from methanol [24]. The process of manufacturing lower olefins from methanol takes place on a mesoporous H-ZSM-5 zeolite catalyst at high temperatures of around $370-500{ }^{\circ} \mathrm{C}$, a process that started in the late 1970 s by Mobil Oil Corporation, with other similar 
processes that use different catalysts available in many plants around the globe today [24]. Moreover, methanol can also be used as a solvent and/or additive in various sectors, such as paint removers, wind-shield washers and it can be used as a fermentation substrate in microbial productions [17].

\subsection{Methanol in Energy Systems}

In recent years there has been a paradigm shift in the use of methanol. As recent as $2012,85 \%$ of the methanol production was used in the chemical industry [22]. However, this is rapidly changing and the use of methanol in the energy sector now accounts for $40 \%$ of methanol consumption [17]. Below some of the uses of methanol in the energy sector are discussed.

\subsubsection{Methanol in Internal Combustion Engines}

Methanol possesses some interesting properties that make it more performing compared to conventional fuels for internal combustion engine; high latent heat, fast-burning velocity, no carbon to carbon bonds, and high octane rating, and hence higher compression ratios and higher knock resistance for an increased engine efficiency $[25,130]$. In fact, its use in engines has been studied as far back as the beginning spark-ignition engines, where methanol was investigated for enhancing the engine performance [130]. Moreover, with its clean-burning and less explosive nature, methanol is the fuel of choice in most competitive motorsports, both due to its high performance and safety compared to other fuels $[12,131]$. However, methanol is corrosive to some metals and can cause swelling of rubber and plastic components, which calls for proper corrosion inhibitors and swelling resistant seals in methanol-based engines.

Despite its early use in internal combustion engines, it was only in the 1980s and 1990s with the California methanol fuel trials that its use as an alternative fuel in internal combustion engine was demonstrated at a larger scale, where 15,000 M85 (85\% methanol) gasoline flex-fuel vehicles of various applications were operated [130]. The program started to reduce NOx emissions, mainly to prevent ozone depletion [132]. Even though the experiment was a technical success it was slowly abandoned in 2004, mainly because natural gas, which was the main source of methanol for the trails, was thought to be scarce and expensive at the time, which was later proven wrong with possibility of nowadays selling methanol from natural gas at half the price of gasoline [133]. Moreover, the oil companies came up with cleaner gasoline by blending it with Methyl Tertiary Butyl Ether (MTBE) to meet california's demands, which however required methanol for its production and diverted it from being used as a substitute to gasoline [133].

China, which is rich in coal but heavily relies on imported oil for its transportation sector, has recently decided to use methanol nationwide as a transportation fuel to tackle both energy security and air pollution challenges [18]. Driven by coal mining permits the Chinese methanol production from coal gasification has reached a production capacity able to cover half of China's transportation fuel demand [130]. Similarly to the California trials of the 1990s, a methanol vehicle pilot program was conducted between 2012 and 2018 in 10 Chinese cities, where more than 1000 methanol vehicles were tested [18]. The program showed methanol's feasibility as a viable transportation fuel with neither techno-economical nor safety issues, and today there are several hundreds of thousands of vehicles that run on pure methanol or methanol blends, including retrofitted vehicles [18]. Despite the coal mining pretext for the methanol production in big quantities in China, the fact that there are no major technical barriers to its use in internal combustion engines and its other numerous applications along with the increasing urgency for climate actions could lead to more investments and progress in renewable methanol production worldwide and establish it as the fuel of the future.

The International Maritime Organization (IMO) has set a new limit in which all sizes of ships will need to use fuel that meets the $0.50 \% \mathrm{~m} / \mathrm{m}$ (mass by mass) SOx emissions from 1 January 2020, lowering it significantly from the current limit of $3.50 \% \mathrm{~m} / \mathrm{m}$ for ships operating outside designated emission control areas [134]. Moreover, there is a plan to cut GHG emissions from international shipping in half by 2050 and successively eliminate them entirely [135]. These increasingly stringent 
emission limits and the fact that methanol is transported in huge amounts in ships is driving an increasing interest in the use of methanol for marine applications as well. At the moment there are a number of projects to test methanol-fueled vessels, including seven new dual-fuel engine chemical tankers, a retrofitted Stena Line ferry, a pilot boat by ScandiNaos, two retrofitted HT-PEMFC tourist boats and others research and development projects [136].

Recently, a study by A.P. Moller - Maersk and Lloyds Register identified alcohols, such as methanol and ethanol, along with biomethane and ammonia as the three main fuels to achieve a net-zero $\mathrm{CO}_{2}$ emissions in the shipping industry [137]. They concluded that alcohols that can be produced from renewable hydrogen and $\mathrm{CO}_{2}$ from biomass or carbon capture have the advantage as they can use proven existing solutions for handling the low flash point and burning and are fully mixable in the vessel's bunker tanks, creating bunkering flexibility.

Similarly, electrofuels can play an important role in decarbonizing aviation [138]. Goldmann et al. [11] investigated five electrofuels, including methanol for use in aviation and found that they can generally replace conventional kerosene-based fuels, but suffer from higher structural loads and potentially lower efficiencies. Moreover, kerosene-based fuels for international aviation remain tax-exempt due to Air Service Agreements (ASAs) made soon after the second world war [138]. Hence, for electrofuels to compete with kerosene-based fuels for aviation, the introduction of such taxes and more stringent fuel standards are required along with carbon pricing and increase in renewable electricity share for cheaper green hydrogen.

\subsubsection{Methanol in Fuel Cells}

In fuel cells, methanol can be used either directly in direct methanol fuel cells (DMFC) or indirectly via methanol steam reforming into hydrogen-rich gas mixture in HT-PEMFCs. The two fuel cell types are described below.

\section{Direct Methanol Fuel Cells (DMFC)}

A direct methanol fuel cell is a variant of proton exchange membrane fuel cells (PEMFC) that use liquid methanol and water mixture instead of hydrogen to generate electricity via electrochemical reactions. This gives DMFC the advantage in terms of fuel handling as liquid mixture can be used without the complications of the hydrogen storage required in the case of low-temperature PEMFC or the added reforming system needed in HT-PEMFC systems. The reactions in a DMFC are given below:

$$
\begin{aligned}
& \text { Anode: } \mathrm{CH}_{3} \mathrm{OH}(\mathrm{l})+\mathrm{H}_{2} \mathrm{O}(\mathrm{l}) \longrightarrow \mathrm{CO}_{2}(\mathrm{~g})+6 \mathrm{H}^{+}+6 \mathrm{e}^{-} \\
& \text {Cathode: } \frac{3}{2} \mathrm{O}_{2}(\mathrm{~g})+6 \mathrm{H}^{+}+6 \mathrm{e}^{-} \longrightarrow 3 \mathrm{H}_{2} \mathrm{O}(\mathrm{l}) \\
& \text { Overall: } \mathrm{CH}_{3} \mathrm{OH}(\mathrm{l})+\frac{3}{2} \mathrm{O}_{2}(\mathrm{~g}) \longrightarrow \mathrm{CO}_{2}(\mathrm{~g})+2 \mathrm{H}_{2} \mathrm{O}(\mathrm{l}) \text {. }
\end{aligned}
$$

DMFCs are suitable for portable power generation due to their power range and rapid refueling characteristics [139]. Consequently, they are usually investigated to replace rechargeable batteries in portable applications. However, there are some practical issues, including their low efficiency of below $30 \%$ due to methanol cross-over through the membrane that limit their widespread application $[140,141]$. High methanol cross-over also means that the fuel cell exhaust contains methanol and possibly formaldehyde, which can cause health concern. To minimize the cross-over the fuel cell should be kept fully hydrated, which requires it to be humidified on both the anode and the cathode side, thereby adding system complexity, limiting the operating temperatures and lowering the achievable electrical efficiency. Moreover, there has been a mismatch between the pace at which they have been developing and the industry's need for readily available solutions, which were met by advances in lithium-ion batteries and efficient microprocessors.

Recently, DMFCs have also been investigated for unmanned aerial vehicle (UAV) applications due to methanol's high energy density [142-144]. However, their lower efficiency and lower power density 
means that higher methanol volume is needed for longer flight time, which inevitably compromises the UAVs payload.

\section{High Temperature PEM Fuel Cells (HT-PEMFC)}

Contrary to DMFCs, reformed methanol fuel cells are an efficient way of using methanol to produce energy, with up to $50 \%$ overall electrical efficiency [145]. A reformed methanol fuel cell (RMFC) or a high temperature PEM fuel cell (HT-PEMFC) is a proton exchange membrane fuel cell that operates at temperatures above $100^{\circ} \mathrm{C}$, typically between $160^{\circ} \mathrm{C}$ and $180^{\circ} \mathrm{C}$. However, unlike low-temperature PEM fuel cells, it does not require liquid water for the proton conduction through the membrane. To achieve appropriate proton conduction at temperatures above the boiling point of water, it employs polybenzimidazole (PBI) membrane, able to conduct protons under anhydrous conditions when doped with phosphoric acid. Therefore, the need for reactant humidification and the associated water management that is crucial in low-temperature PEM fuel cells is eliminated, thereby avoiding the risk of cell flooding or drying. The reactions that take place in an HT-PEMFC are the same as those of a low-temperature PEM, and are given as follows:

$$
\begin{aligned}
\text { Anode }: & 2 \mathrm{H}_{2}(\mathrm{~g}) \longrightarrow 4 \mathrm{H}^{+}+4 \mathrm{e}^{-} \\
\text {Cathode }: & \mathrm{O}_{2}(\mathrm{~g})+4 \mathrm{H}^{+}+4 \mathrm{e}^{-} \longrightarrow 2 \mathrm{H}_{2} \mathrm{O}(\mathrm{g}) \\
\text { Overall }: & 2 \mathrm{H}_{2}(\mathrm{~g})+\mathrm{O}_{2}(\mathrm{~g}) \longrightarrow 2 \mathrm{H}_{2} \mathrm{O}(\mathrm{l}) .
\end{aligned}
$$

The higher operating temperature of HT-PEMFC comes with an added advantage of higher tolerance to impurities in the fuel compared to their lower temperature counterparts [146-148]. In fact, it is possible to use the product gas of methanol steam reforming, known as reformate gas $\left(\mathrm{H}_{2}, \mathrm{CO}_{2}\right.$, and traces of $\mathrm{CO}$ and unconverted methanol-water mixture) directly in the fuel cell without any pre-purification, giving HT-PEMFCs big advantages in terms of fuel flexibility [149]. A comprehensive review of the core PBI-based HT-PEMFC technology and its components and their characterization can be found in our previous work [150]. Therefore, the focus of this review is not on the core HT-PEMFC technology but rather on the whole system and its role in the methanol economy.

A reformed methanol fuel system with all its main components is shown in Figure 5. The process starts in the catalytic burner, which uses some of the fuel to heat up the reformer. In the reformer, steam and methanol fed through an evaporator are heated up further to produce the reformate gas, which is then directed to the fuel cell to produce electricity. The evaporator recovers heat from the fuel cell stack exhaust air and coolant. In some cases the reformate gas can be cooled down in a separate heat exchanger to reach the fuel cell stack operating temperature. Once the systems is started, the reformate exhaust from the anode off-gas can be recycled in the burner.

As can be seen in Figure 5, HT-PEMFC systems have the possibility of heat integration of hot and cold streams, where at least two reactors which require heat can be identified, i.e., the endothermic methanol steam reformer and the evaporator. On the other hand the fuel cell stack and the burner release heat, although the fuel cell stack requires heat during system start-up in order to reach operating temperature. In [151], a strategy to ensure proper heat integration over all the load ranges was suggested. The principal idea is to provide extra fuel to the burner whenever the heat provided by the depleted fuel and air at the stack outlets is not sufficient. It was found that below a certain load, anode stoichiometric ratio must be increased in order to provide enough heat to the burner to sustain both the reforming and fuel cell reactions. In other words, the amount of fuel mix that is sent to the fuel cell stack must be larger than what is strictly required for the electrochemical reactions to take place.

An alternative strategy for the warming up of the stack during the start up phase was investigated in [152], where alternating current is applied directly to the stack with a suitable frequency aimed at heating the stack's main ohmic resistances (i.e. membrane and contact resistance). The strategy was found to reduce the start-up time compared to more conventional strategies based on external liquid coolant. 


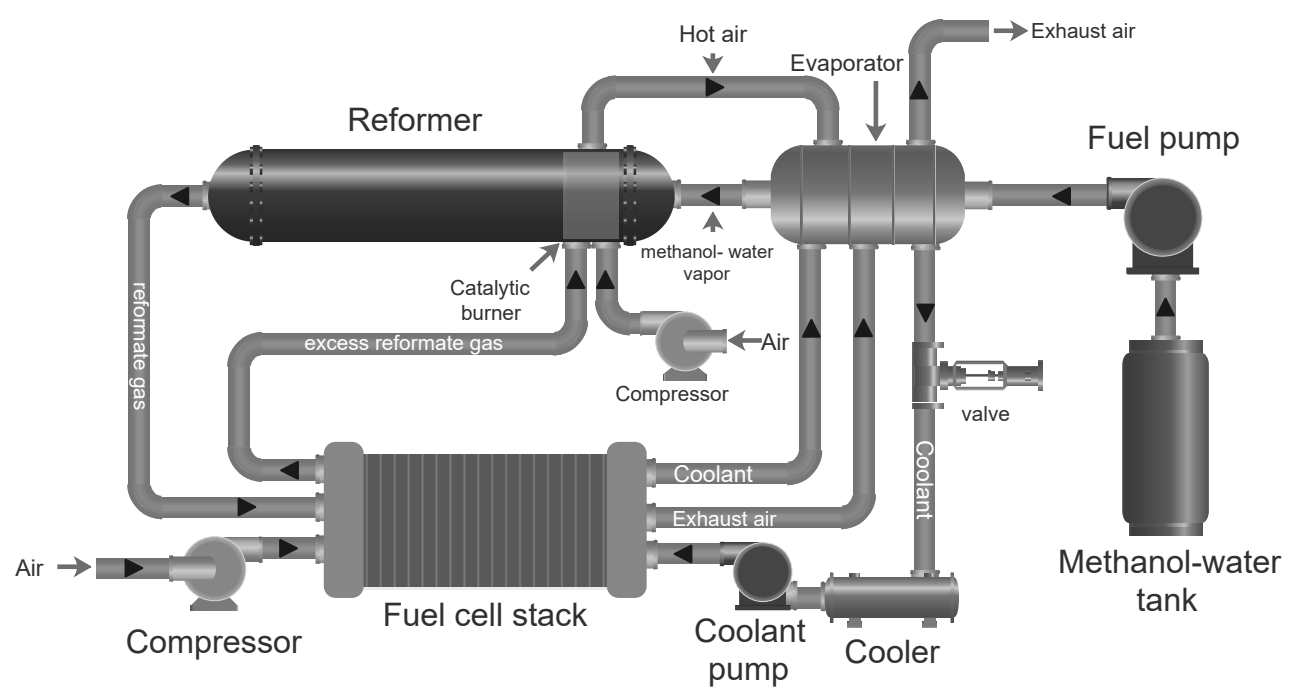

Figure 5. A schematic of a reformed methanol fuel cell system.

The use of different fuels requires different heat integration strategies and can affect the electrical efficiency of the system. In [151], it was shown that in an ideal case a methanol-fed system shows a better efficiency compared to a hydrogen-fed system. This can be attributed to the fact that in the system with the methanol reformer, the heat in the depleted gas at the stack outlet can be reused for the endothermic reforming process. However, it is worth noting that even though HT-PEMFC has a higher tolerance to $\mathrm{CO}$ in the reformate mixture, this can still reduce the cell performance and lifetime compared to a hydrogen-fed system.

Methanol Reforming

The process of catalytically converting hydrocarbons into a hydrogen-rich gas mixture is known as reforming. The process requires an oxidizing agent and if water vapor is used for this purpose, the process is known as steam reforming, which is endothermic and requires permanent external heating to be sustained. If on the other hand, air is used as the oxidant the process is an exothermic one called partial oxidation, whereas if both water and air are used the process is called autothermal reforming, which is a combination of the two processes with net reaction enthalpy change of zero [153].

Methanol, which is the simplest alcohol with only one carbon atom has one of the lowest reforming temperatures of only $200-300{ }^{\circ} \mathrm{C}$ owing to the absence of a strong $\mathrm{C}-\mathrm{C}$ bond $[154,155]$. The single carbon configuration gives it a high $\mathrm{H} / \mathrm{C}$ ratio of $4: 1$, which results in high concentration of $\mathrm{H}_{2}$ in the reformate mixture for use in an HT-PEMFC. It is also liquid at ambient conditions with a boiling point of around $65^{\circ} \mathrm{C}$ and completely miscible with water, and hence, easy to store and transport [22]. The most widely used reforming process in conjunction with HT-PEMFCs is methanol steam reforming (MSR) as it produces high concentration $\mathrm{H}_{2}$ per mole of methanol according to reaction 11, which is an algebraic sum of the water gas shift reaction (WGS) in reaction 12 and the methanol decomposition (MD) in reaction 13 [154,156,157].

$$
\begin{gathered}
\text { MSR : } \mathrm{CH}_{3} \mathrm{OH}+\mathrm{H}_{2} \mathrm{O} \rightleftharpoons \mathrm{CO}_{2}+3 \mathrm{H}_{2} \\
\text { WGS }: \mathrm{CO}+\mathrm{H}_{2} \mathrm{O} \rightleftharpoons \mathrm{CO}_{2}+\mathrm{H}_{2} \\
M D: \mathrm{CH}_{3} \mathrm{OH} \rightleftharpoons \mathrm{CO}+2 \mathrm{H}_{2}
\end{gathered}
$$

$$
\begin{aligned}
& \Delta H_{298 \mathrm{~K}}=+49.7 \mathrm{~kJ} \mathrm{~mol}^{-1} \\
& \Delta H_{298 \mathrm{~K}}=-41.2 \mathrm{~kJ} \mathrm{~mol}^{-1} \\
& \Delta H_{298 \mathrm{~K}}=+90.2 \mathrm{~kJ} \mathrm{~mol}^{-1}
\end{aligned}
$$

Copper-based catalysts, such as $\mathrm{Cu} / \mathrm{ZnO} / \mathrm{Al}_{2} \mathrm{O}_{3}$ are currently the most widely used commercial catalysts for hydrogen production for fuel cell systems with relatively good activity and selectivity, where $\mathrm{Cu}$ acts as the active component [158-160]. The reforming activity on $\mathrm{Cu} / \mathrm{ZnO} / \mathrm{Al}_{2} \mathrm{O}_{3}$ starts at $160{ }^{\circ} \mathrm{C}$ [156], which would be ideal from a system integration point of view with an HT-PEMFC 
that typically works between $160-180{ }^{\circ} \mathrm{C}$. However, even at around $200{ }^{\circ} \mathrm{C}$ around $8 \%$ of unconverted methanol slip can be present in the reformate mixture, an amount that is detrimental to HT-PEMFC's performance and lifetime [161,162]. Therefore, it is only above $230^{\circ} \mathrm{C}$ that a steam methanol reformer can produce a clean enough reformate mixture $(\leq 2 \%$ methanol and $\leq 1 \% \mathrm{CO})$ that is usable in an HT-PEMFC without a cleanup process and without compromising the performance and durability of the fuel cell.

The $\mathrm{CO}$ concentration in the reformate mixture increases with increasing reforming temperature, while the unconverted methanol concentration decreases due to higher conversion rates at higher reforming temperatures. However, even though the harmful effect of $\mathrm{CO}$ on performance increases with increasing CO concentrations, an HT-PEMFC can tolerate higher CO concentrations of up to $5 \%$ with only small performance decay, especially at higher operating temperatures and lower current densities [150]. In comparison, low-temperature PEM fuel cell can only tolerate a few parts per million of $\mathrm{CO}$ concentrations in the anode feed. Nonetheless, the lower the CO concentrations in the reformate mixture the better it is for the fuel cell both in terms of performance and durability.

Therefore, since methanol slip and $\mathrm{CO}$ concentration have opposite trends with respect to reforming temperature, an optimal reforming temperature and proper control of the flow rates are required to obtain a proper reformate mixture. An experimental mapping of the methanol and $\mathrm{CO}$ concentrations in the reformate gas with respect to reformer temperature at the inlet are shown in Figure 6 [161].

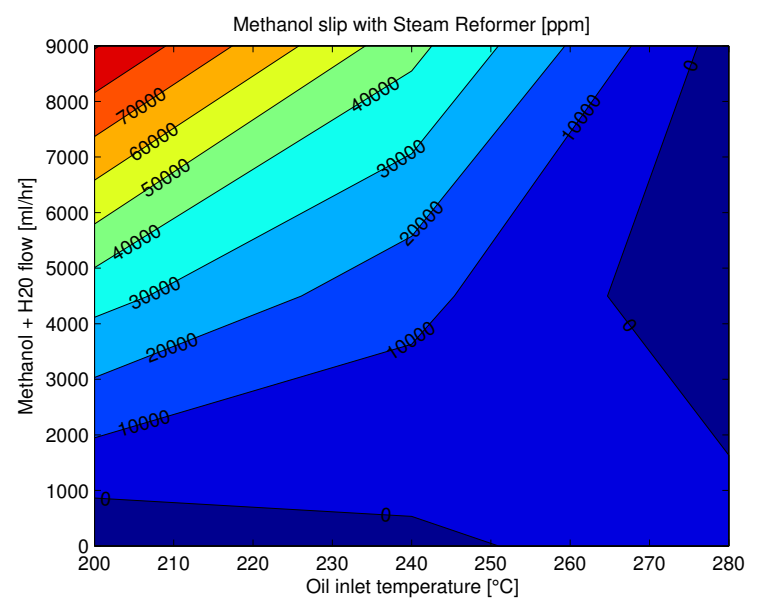

(a)

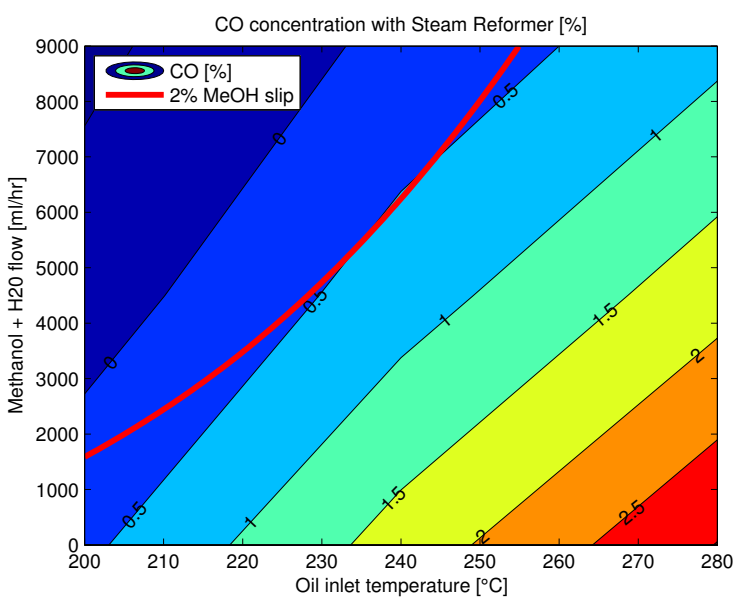

(b)

Figure 6. Reformate composition at the steam methanol reformer outlet at different reforming temperatures (given by the temperature at the inlet of the reformer) (a) Methanol concentration in reformate mixture at different reforming temperatures $(b) \mathrm{CO}$ concentration in reformate mixture at different reforming temperatures, with the red line showing the $2 \%$ methanol slip. Reprinted with permission from [161]; 2016, Aalborg Universitetsforlag.

In order to limit concentrations of undesired byproducts, including unconverted methanol in the reformate gas, catalysts for steam reforming should have high activity and fast kinetics at low temperature, high selectivity in order to suppress CO production, and good stability, and long lifetime [163]. Moreover, catalysts with well-dispersed and smaller crystallite size particles and higher specific surface area of copper generally result in better performance [164]. An extensive review of the influence of catalyst components and preparation methods on the performance of different Cu-based catalysts for MSR can be found in [163].

Catalyst deactivation generally happens due to thermal sintering above $300{ }^{\circ} \mathrm{C}$ with recommended operating temperatures of below $260^{\circ} \mathrm{C}$ [164]. Coke deposition due to iron or other transition metals, wax or carbon formation due to silica reaction with alumina, and catalyst poisoning with sulfur and chloride content in the reactants are other deactivation mechanisms that have been observed for such 
catalysts in methanol steam reforming [165]. In order to maintain the chemical and thermal stability of $\mathrm{Cu} / \mathrm{ZnO}$-based catalysts in industrial application, $\mathrm{Al}_{2} \mathrm{O}_{3}$ or other substitutes are often added as stabilizers or promoters $[165,166]$.

To overcome the problem of active phase sintering, the metals in groups 8 to 10 of the periodic table have also been studied as catalysts with higher thermal stability and similar selectivity compared to Cu-based catalysts [163]. Moreover, increasing the steam to carbon ratio in the feed of methanol-steam mixture decreases the catalyst deactivation rate [167], since the absence of water vapor can lead to coke formation that in turn can block catalyst pores and exacerbate their deactivation [168,169].

Conventional packed-bed reformers use catalysts in the form of pellets due to relatively low cost of preparation and ease of operation [170], despite being characterized by larger thermal gradient between the tube wall and the interior catalyst bed [155]. Recently, advanced micro-processing is making it increasingly possible to manufacture well-structured micro-channel reactors with wall-coated catalysts, which present fewer heat and mass transfer limitations [154]. Catalytic membrane reactor (CMR) with palladium-based membranes is another novel technology with improved process efficiency, where methanol steam reforming occurs on the tube side and hydrogen is permeated through a membrane and continuously collected on the shell side allowing to shift the reaction equilibrium towards the products, thereby improving methanol conversion [171].

\section{HT-PEMFC Technology Status and Prospects}

Reformed methanol fuel cells, like all fuel cells, are scalable and versatile and can be used in a variety of applications. They are investigated for stationary application; such as backup power for telecom application [145], uninterrupted power unit (UPS) [172], combined heat and power (CHP) generation for residential applications [173], and for portable power generation; as well as in automotive applications, both as auxiliary power units (APU) [172] for boats and road vehicles [174] and as range extenders $[175,176]$.

A number of projects at demonstration and some at commercialization level have shown the potential for reformed methanol-fueled HT-PEM fuel cells in different applications. In automotive applications, reformed methanol fuel cell systems have been predominately used as range extenders in combination with batteries. In the European project ARTEMIS [177], the possibility to use a HT-PEM power train on a light-duty, commercial vehicle was investigated. Another example is in the danish municipality of Aalborg, where a methanol filling station was opened in 2015 to refill methanol fuel cell cars including a prototype of a Fiat 500 powered by a 5kW HT-PEM Stack, developed ad hoc for the demonstration project [175]. Recently, a Denmark-based company Blue World Technologies has started the development of a methanol-fueled HT-PEM fuel cell system for automotive application [178]. The company is betting on the technology and has a partnership with a Chinese electric vehicle manufacturer AIWAYS to supply the market with methanol fuel cell cars [176].

In the maritime sector, a project by the name e4ship funded by the German government demonstrated a 90kW system based on a methanol HT-PEMFC stack on the ferryboat Mariella from the Viking line. The system compromises 5KW fuel cell modules with methanol-reforming units for conversion of methanol into hydrogen [179]. In another demonstration project in the municipality of Essen in Germany a touristic vessel on the Lake Baldeneysee was powered by a 35 kW HT-PEM fuel cell system fueled by methanol [180]. For both these projects the fuel cells were developed by the Denmark-based fuel cell manufacturer SerEnergy.

HT-PEM fuel cells for residential CHP applications have also seen some development in the past few years. Demonstration projects have mainly used natural gas as a fuel for the already available distribution infrastructure. With little adaptation of the reforming process, these systems can operate with a variety of fuels, including methanol. Besides, HT-PEM fuel cells have the advantage of providing high-quality heat, which matches with the residential application requirements. In the Eurostars project HyRIS a micro CHP system was developed by the Germany-based Fuel Cell Research Center, ZBT, and the company Advent Technologies in Greece [181]. In another European demonstration project 
called ene-Field more than 1000 CHP units, including HT-PEMFC-based ones, have been tested in 10 European countries in the years between 2012-2017 [182]. The HT-PEMFC systems for residential use in this project delivers $300 \mathrm{~W}$ electric power and $600 \mathrm{~W}$ thermal power, where the small energy output offers cost-saving compared to the conventional energy supplier [183].

In UPS applications, methanol-fueled HTPEM systems are developed and commercialized by Serenergy [172]. The systems are targeted mainly for telecom applications in remote regions where conventional diesel generators are currently used.

For the commercial success of HT-PEMFCs, further development of more resistant materials and improved system integration and control designs are necessary to increase their lifetime. Bipolar plates with excellent corrosion resistance, low bulk density and high electrical conductivity [184], and methanol steam reformer which maximizes the heat transfer with a uniform flow distribution and low-pressure drop [185], are significant to reduce the balance-of-plant component number, size, mass, and ultimately cost.

The efficient heat integration is another key issue that needs to be addressed. An integrated stack-reformer system was demonstrated by Pan et al. [186] but with low hydrogen yield due to the lower operating temperature of the reformer at $200{ }^{\circ} \mathrm{C}$. Ji et al. [187] tested an internal reforming fuel cell (IRMF) with methanol solution and air and achieved power density of $0.45-0.55 \mathrm{~W} / \mathrm{cm}^{2}$ at 180-200 ${ }^{\circ} \mathrm{C}$. However, they reported instability of the single cell at high current density.

Lotrič et al. [146] compared the heat-integrated systems capable of producing $25 \mathrm{~W}$ of gross electric power for use in portable applications. The results indicated that the system of integrated HT-PEMFC stack and methanol steam reformer was feasible and had higher system efficiency than the system with LT-PEMFC stack. Ribeirinha et al. [147] studied the thermal integration of a low-temperature methanol steam reforming cell with an HT-PEMFC in a combined stack arrangement. In addition, the degradation of the membrane electrode assembly (MEA) due to the methanol in the reformate stream was observed and investigated by using EIS analysis.

\section{Methanol Versus Hydrogen: a Comparison between Two Energy Carriers for Fuel Cells}

In this section, two pathways for storing renewable electricity for use in fuel cells, namely the methanol pathway and the compressed hydrogen pathway have been compared. As comparison parameters; emissions, energy efficiency, and cost were considered as they are likely to determine the future outlook of the two pathways. Figure 7 illustrates the two scenarios with the automotive application as an example.

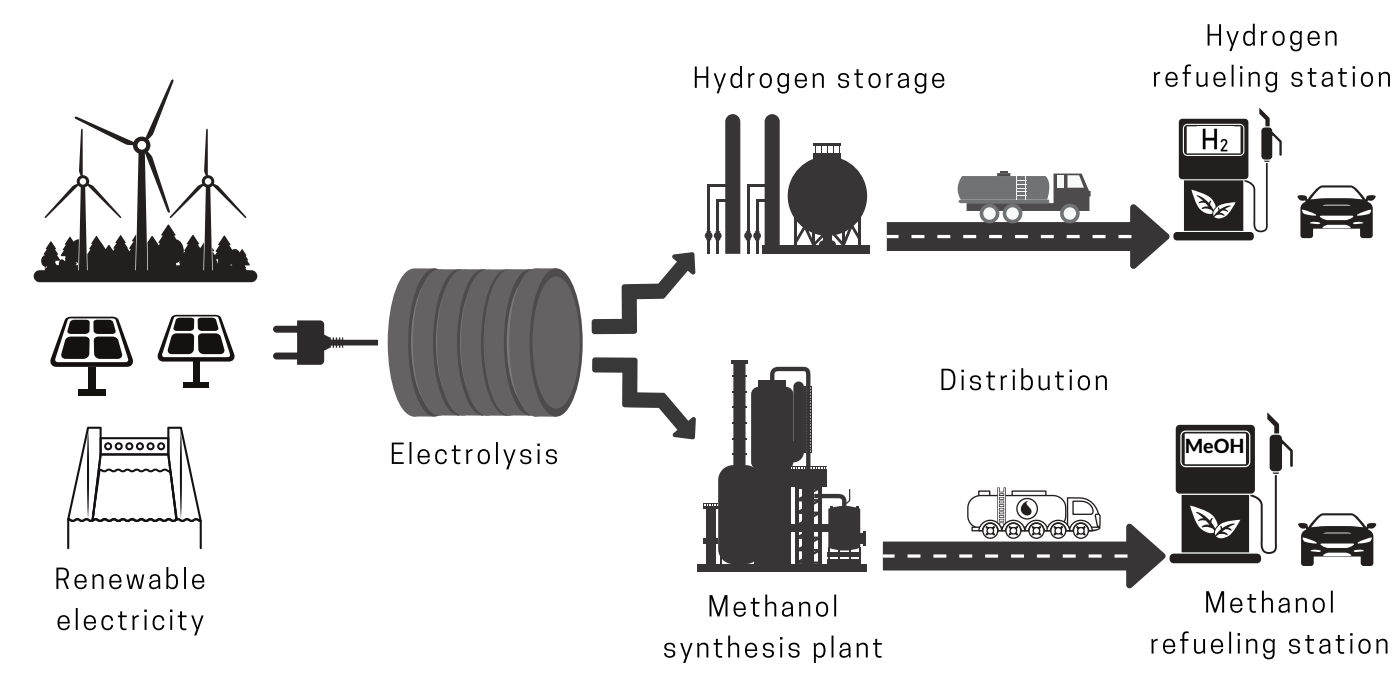

Figure 7. Renewable energy transformation pathways in the cases of methanol and hydrogen as energy carriers. 


\subsection{Emissions}

The two pathways can be said equally carbon-neutral when electrolysis by renewable electricity is used to produce hydrogen, both for direct use and as a feedstock for the methanol pathway granted that the $\mathrm{CO}_{2}$ source is also renewable, i.e, from biomass or via carbon capture from the atmosphere. However, as is usually the case that the more complex a compound is the more intermediates and emissions its reactions produce, methanol despite being the simplest alcohol is much more complex than hydrogen. While the emission from hydrogen fuel cell is only water, both combustion reactions in the burner and the methanol steam reforming in the fuel cell system produce $\mathrm{CO}_{2}$, even though the cycle is $\mathrm{CO}_{2}$ neutral for green methanol.

Owing to methanol's single carbon structure, its combustion is characterized by significantly lower NOx and particulate matter content compared to complex hydrocarbon fuels [130]. Moreover, only a small amount of methanol is used in the burner during the system start up and then the reformate mixture from the anode off-gas is used to further sustain the burner, which makes the RMFC system emissions much lower than those of methanol-fed internal combustion engines.

Another possible emission from methanol-based systems is formaldehyde, which is an intermediate species in the reaction pathway of methanol oxidation and can constitute health concern $[130,188]$. Similarly, this is more an issue for methanol combustion in internal combustion engines than in reformed methanol fuel cells. The only risks of formaldehyde formation in an RMFC system are from the catalytic burner during system startup or in case of poor methanol conversion in the reformer, where some unconverted methanol enters the fuel cell stack and crosses through the membrane electrode assembly (MEA), where it reacts with oxygen on the cathode side. Therefore, it can be concluded that there are no harmful emissions from the system under normal reformer and fuel cell system operation, and that the overall process is carbon-neutral if green methanol is used.

At the point of use, hydrogen in fuel cells with only water vapor as a byproduct is the clear winner. However, a thorough life cycle assessment that considers all the processes, including methanol synthesis and transportation and hydrogen compression/liquefaction and transportation is required to make a proper life cycle impact assessment comparison between the two pathways.

\subsection{Energy Efficiency}

Energy efficiency comparison between the methanol and hydrogen pathways are given in Table 1. Many of the processes are similar for the two pathways, such as the power conditioning and transmission from point of renewable electricity production to point of hydrogen production by electrolysis and the fuel cell electrical energy generation. A similar analysis was presented in [189], where different process routes were evaluated and compared using methanol and hydrogen as energy storage media.

Table 1. Process energy efficiency comparison between methanol and hydrogen as a source of fuel for fuel cell electricity production.

\begin{tabular}{|c|c|c|c|c|c|}
\hline \multirow[t]{2}{*}{ Step } & \multicolumn{2}{|c|}{ Energy Conversion Route } & \multicolumn{2}{|c|}{ Process Efficiency } & \multirow{2}{*}{ Reference } \\
\hline & Methanol & Hydrogen & Methanol & Hydrogen & \\
\hline 1 & \multicolumn{2}{|c|}{ Power Management, Conditioning and Transmission } & \multicolumn{2}{|c|}{$90 \%$} & [190] \\
\hline 2 & \multicolumn{2}{|c|}{$\mathrm{H}_{2}$ production by electrolysis } & \multicolumn{2}{|c|}{$\begin{array}{c}\mathrm{PEMEC} \rightarrow 78 \% \\
\mathrm{AEC} \rightarrow 74 \% \\
\mathrm{SOEC} \rightarrow 96 \%\end{array}$} & $\begin{array}{l}{[191]} \\
{[192]} \\
{[71]}\end{array}$ \\
\hline 3 & Methanol synthesis & $\mathrm{H}_{2}$ compression & $79(69-89) \%$ & $75(65-85) \%$ & [83] \\
\hline 4 & \multicolumn{2}{|c|}{ Fuel transportation } & $99 \%$ & $95 \%$ & [193] \\
\hline 5 & Methanol Fuel cell system & Hydrogen Fuel cell system & $50 \%$ & $60 \%$ & {$[145,194]$} \\
\hline
\end{tabular}


Firstly, due to power conditioning, transmission losses, and electricity management around $10 \%$ of energy input is lost in the process from renewable energy sources to the electrolyzer plant [190]. Then, if a PEM electrolyzer system is used efficiencies based on hydrogen $\mathrm{HHV}$ of around $78 \%$ can be obtained [191]. In [195], similar values were reported for large electrolyzer plant. Although such a value is expected to be reduced in the cases of pressurized operation and due to system degradation. Major improvements in the nominal efficiency values are not expected in the future as the long term efficiency targets have already been achieved, and hence, research and development efforts are focusing rather on reducing system cost [192]. Alkaline electrolyzers deliver hydrogen at a lower efficiency of around $74 \%$ compared to PEM electrolyzers [192].

The differences in energy efficiency between the methanol and hydrogen pathways arise after hydrogen production during fuel processing, storage and distribution, and refueling. As described previously, methanol can be produced by hydrogenation of $\mathrm{CO}$ and $\mathrm{CO}_{2}$ from renewable sources such as biomass or from industrial activities. Fornero et al. [196] studied a methanol reactor performance at different $\mathrm{H}_{2}$ and $\mathrm{CO}_{2}$ molar fractions and he revealed that increasing the hydrogen concentration increases the efficiency. Similarly, Clausen et al. [197] made a model based on different configurations for sourcing $\mathrm{H}_{2}$ and $\mathrm{CO}_{2}$ and found that the reactants stoichiometric ratios affect the system efficiency. Brynolf et al. [83] reported a methanol synthesis efficiency in the range of $69 \%$ and $89 \%$. These values assume that the process is fully heat integrated and that there are only $10 \%$ heat losses. It is also worth noting that methanol synthesis processes produce crude methanol, which requires a distillation process to remove the gases and water content to obtain pure methanol. This may affect the overall efficiency depending on the number of distillation columns used.

In order to be transported conveniently, hydrogen must be compressed, liquefied, stored in metal hydrides, or converted to liquid fuels. As the most adopted option so far for the automotive application, the compressed hydrogen storage is considered here for the hydrogen pathway. The automotive industry has opted for a 700 bar pressurized tank storage solution [198]. A detailed review of all the hydrogen compression methods is provided in [193]. In the study it is mentioned that diaphragm compressors have proven to be an efficient and reliable method for hydrogen compression, with efficiency values scattered in the range between 65 and $85 \%$. Metal hydride alloys can be another option however, in this case the gravimetric energy density will be strongly reduced and efficiency values will be in the range of $25 \%$ [193].

Hydrogen and methanol are generally produced in plants that can be distant from the point of use. In the case of fuel cell vehicles, the fuel has to be transported to the refuelling station. Therefore, the assessment is strongly dependent on the distance between the point of purchase and the point of production, the type of truck, etc. In the future these values can be reduced due to additional efficiency improvements in the supply chain. Nonetheless, methanol has the advantage of being in liquid form at ambient temperature and pressure. The fuel storage and distribution are therefore very similar to what is currently done for gasoline and diesel for vehicles and it can be shipped in large volume and long-distance in boats and rail.

In the final step, the fuel is converted into electricity in a fuel cell system. Heat-integrated methanol-fueled HT-PEMFC systems have demonstrated an efficiency of up to 50\% [145], while hydrogen-fueled PEM systems have shown better efficiencies in the range of $60 \%$ [194]. The difference in the efficiency can be attributed, among other reasons, to the methanol reforming process and the lower concentration of hydrogen gas in the HT-PEMFC system.

\subsection{Cost Analysis}

In the cost analysis of the two pathways, hydrogen production is common to both with projected investment costs for the year 2030 of around $700-800 €_{2015} / \mathrm{kW}_{e l}$ for all the main electrolyzer types, considering some technological advancements and mass production [83]. However, the methanol pathway has additional cost for the required $\mathrm{CO}_{2}$, which has to be renewable or somehow alleviate emissions from carbon-intensive industries. Potential such $\mathrm{CO}_{2}$ sources include air and production 
facilities for various processes, such as biofuels, oil and gas refineries, power and heat, iron and steel, cement and lime, pulp and paper, etc. [199]. The concentration of $\mathrm{CO}_{2}$ in these sources ranges from around $407 \mathrm{ppm}$ in air [200], to above $90 \mathrm{vol} \%$ in biofuel plants [199]. This can significantly affect the $\mathrm{CO}_{2}$ capture costs, ranging from as low as $10 €_{2015} /$ ton $\mathrm{CO}_{2}$ for pure streams such as biofuel plants [199] up to $232 \$(\sim 207 €) /$ ton $\mathrm{CO}_{2}$ from the atmosphere [201].

Hansson et al. [199] estimated the cost of production of green methanol to be $210 €_{2015} / \mathrm{MWh}_{\text {fuel }}$ in 2015 and is expected to fall to $160 €_{2015} / \mathrm{MWh}_{\text {fuel }}$ in 2030. They assumed methanol synthesis plant efficiency of $79 \%$, cost of electricity for $\mathrm{H}_{2}$ production at $50 €_{2015} / \mathrm{MWh}$ and cost of $\mathrm{CO}_{2}$ capture at 30 $€_{2015} /$ ton $\mathrm{CO}_{2}$.

Clausen et al. [197] performed a techno-economic analysis of methanol plants based on gasification of biomass and electrolysis of water, where they compared six different configurations with different energy inputs used for the syngas production. They found estimated methanol costs between 42.5-52.6 $€ / \mathrm{MWh}_{\text {fuel }}$ for all the five configurations that included biomass or biogas, while the configuration with hydrogen from electrolysis of water and $\mathrm{CO}_{2}$ from post-combustion capture at a power plant had a higher estimated methanol cost of $91 € / \mathrm{MWh}_{f u e l}$, of which $65 \%$ is the electricity price. Nonetheless, this is still significantly lower than the estimated cost of methanol from atmospheric $\mathrm{CO}_{2}$ capture. A cost analysis of the methanol and hydrogen pathways based on a literature survey is given in Table 2 .

Table 2. Cost analysis of the methanol and hydrogen pathways for fuel cell electric vehicle application. Only prices for green and grey methanol are considered in the comparison.

\begin{tabular}{|c|c|c|c|c|c|}
\hline \multirow{2}{*}{ Step } & \multicolumn{2}{|c|}{ Process/Equipment/Raw Material } & \multicolumn{2}{|c|}{ Cost } & \multirow[t]{2}{*}{ Reference } \\
\hline & Methanol & Hydrogen & Methanol & Hydrogen & \\
\hline 1 & \multicolumn{2}{|c|}{ Electricity } & \multicolumn{2}{|c|}{$40-50 € / \mathrm{MWh}$} & {$[197,199]$} \\
\hline 2 & \multicolumn{2}{|c|}{ Electrolyzer } & \multicolumn{2}{|c|}{$600-800 € / \mathrm{kW}_{e l}$} & {$[83,191]$} \\
\hline 3 & Methanol synthesis & $\mathrm{H}_{2}$ compression & $42.5-400 € / \mathrm{MWh}_{\text {fuel }}$ & $\sim 3.2 € / \mathrm{MWh}_{\text {fuel }}{ }^{1}$ & {$[83,193,197]$} \\
\hline 4 & \multicolumn{2}{|c|}{ Fuel transportation } & negligible & $\sim 8 € / \mathrm{MWh}_{\text {fuel }}{ }^{2}$ & [202] \\
\hline 5 & \multicolumn{2}{|c|}{ Refueling station $^{3}$} & $\sim 182,000 €$ & 1.4-2.7 million $€$ & [203-205] \\
\hline
\end{tabular}

In [195], an estimation of the energy cost for hydrogen handling and transmission in the automotive sector was reported. Assuming different feedstocks for the production of hydrogen and considering spatial and temporal aspects of $\mathrm{H}_{2}$ infrastructure for the Netherlands, they found that regardless of the origin, feedstock contributes the most to the total cost with $40 \%$, while transportation accounts for around $10 \%$ and refueling stations for around $17 \%$.

Demir and Dincer [202] compared three different scenarios of hydrogen delivery, namely, pressurized tanks, cryogenic liquid hydrogen tanker, and gas pipelines. They concluded that for hydrogen production from large-scale plants, delivery with pipeline network is the most cost-effective and most environment friendly option at levelized costs of $2.73 \$ / \mathrm{kg} \mathrm{H}_{2}\left(\sim 74.4 € / \mathrm{MWh}_{\text {fuel }}\right)$, whereas liquefied hydrogen storage increases the capital cost significantly to $8.02 \$ / \mathrm{kg} \mathrm{H}_{2}\left(\sim 218 € / \mathrm{MWh}_{\text {fuel }}\right)$ and there can also be $\mathrm{CO}_{2}$ emissions associated with the high electricity consumption by the liquefier. They also concluded that for hydrogen from small-scale plant truck delivery is more cost-effective than pipeline networks due to the relatively high cost of pipeline construction.

Compressors are needed both in the terminal for filling tankers and in the refueling stations. Even though the capital cost of the compressors in the refueling stations are included in the overall investment cost of the stations, capital cost of compressor at the large scale hydrogen dispensing plant need to be considered when the electrolysis is not onsite. For instance the capital cost of reciprocating 
compressor is around $150,000 \$(136,000 €)$, with added operation and maintenance cost of around 5\% of the capital cost [193].

On the use end, the hydrogen refueling infrastructure requires a significant investment cost compared to methanol. However, in the comparison between the two pathways this cost may be offset by the cost of added methanol production capacity for the transportation sector. Ogden et al. [203] compared the capital cost of developing hydrogen refueling infrastructure based on near term technologies with methanol infrastructure and found that while the methanol infrastructure cost would be low initially (less than $50 \$(\sim 45 €) /$ car), it would increase to 330-770 \$( 300-700€)/car once new methanol production capacity was needed, exceeding the estimated hydrogen infrastructure cost of 310-620 \$ ( 282-563€)/car depending on the type of hydrogen supply.

On the other hand, the existing distribution infrastructure for gasoline can be used for methanol with modification cost of around $\sim 45,000 \$(\sim 41,000 €)$ per refueling station that delivers around $\sim 4.2 \mathrm{~m}^{3}$ of methanol per day [203]. The cost of hydrogen refueling stations is dependent on the geographical area, the size of the station and on whether the electrolysis process is present in the refueling station or hydrogen is transported from elsewhere. It is reported that in Japan the construction cost can go up to 3 million $\$(\sim 2.7$ million $€)$ per refueling station [205]. Furthermore, in a comparison between infrastructure capital expenditure (CAPEX) using 10,000 gasoline stations network as a benchmark, it was reported that the cost would be 2 billion $\$$ (1.8 billion $€$ ) for equivalent new liquid fuel stations network and around 1.4 trillion $\$(1.3$ trillion $€$ ) for the hydrogen infrastructure [204]. However, this comparison only considers the distribution infrastructure without taking into account the capital cost of the additional methanol production capacity, which as mentioned above can be comparable to the cost of the hydrogen infrastructure.

A direct comparison of the investment cost for the two pathways is not easy for various reasons, such as technology readiness and market uptake. Consequently, the values reported in the literature are not consistent. Nonetheless, it can be said that $\mathrm{CO}_{2}$ capture is still costly with current regulations of $\mathrm{CO}_{2}$ pricing and trading schemes. The methanol from $\mathrm{CO}_{2}$ capture pathway is expected to reach an economic feasibility when $\mathrm{CO}_{2}$ capture cost goes below $10 € /$ ton $\mathrm{CO}_{2}$ and electricity cost is below 20 $€ /$ MWh [197].

\section{Conclusions and Future Outlook}

This paper provides a review of the methanol economy, where methanol produced by renewable means is used in the chemical industry and in the energy sector as a substitute for fossil-based alternatives. The renewable methanol production from hydrogen obtained via water electrolysis from excess renewable electricity and renewable $\mathrm{CO}_{2}$ from a variety of feedstocks was examined. The traditional methanol production method through syngas to methanol (STM) process, as well as the necessary adaptations towards the new generation $\mathrm{CO}_{2}$ to methanol (CTM) process for sustainable methanol production, were discussed. The use of methanol both in the chemical industry and the energy sector were explored, with a special attention on high-temperature PEM fuel cells, where all the components and processes of an integrated reformed methanol fuel cell system were described. Finally, renewable methanol and compressed hydrogen pathways were compared as renewable electricity storage solutions with the automotive application as an example. The comparison was based on environmental impact, energy efficiency and cost analysis.

Even though the transition to an entirely sustainable economy is slow due to limited availability and intermittency of renewable sources, methanol and other storage solutions can alleviate these issues by storing excess renewable electricity for later use and support increased penetration of renewable energy sources. The cost of $\mathrm{CO}_{2}$ capture for methanol production depends heavily on the $\mathrm{CO}_{2}$ streams used. While it is relatively inexpensive for pure streams such as those in biofuel plants, where $\mathrm{CO}_{2}$ concentration can reach up to $90 \mathrm{vol} \%$, the cost is still too high for a commercially viable implementation of green methanol production from atmospheric $\mathrm{CO}_{2}$ capture. Therefore, more work is needed to reduce the cost of $\mathrm{CO}_{2}$ capture in order to drive down the cost of green methanol. 
Other than through technological advancements, this can be enhanced through appropriate carbon pricing and trading schemes. Moreover, increased renewable electricity penetration can lead to a lower cost of electricity for hydrogen production, which at the moment contributes significantly to the overall production cost.

High-temperature PEM fuel cells that run on reformed methanol have been demonstrated in several applications. However, more application-specific systems need to be developed to aid their commercial deployment. For instance, for automotive application in order to optimize space and weight, it is desirable to carry pure methanol tanks instead of the commonly used pre-mixed methanol-water mixture. Future research should address the use of water recovered from the fuel cell's electrochemical reactions to sustain the methanol steam reforming. Further research on non-noble catalysts and metallic bipolar plates for HT-PEMFCs could contribute to cost reduction and increased volumetric energy density. Moreover, despite the significant improvement achieved on the durability of stack components over the past decade, more work is needed to achieve satisfactory system durability and availability. Diagnostic tools embedded in the fuel cell control system could be used to enhance the durability and availability of HT-PEMFC systems through lifetime estimation and condition-based interventions.

Author Contributions: Conceptualization, S.S.A. and V.L.; methodology, S.S.A. and V.L.; formal analysis, S.S.A., V.L. and X.C.; investigation, S.S.A., V.L., X.C., N.L., J.Z. and S.L.S.; data curation, S.S.A. and V.L.; writing-original draft preparation, S.S.A., V.L., X.C., N.L., J.Z. and S.L.S; writing-review and editing, S.S.A., V.L., S.L.S., S.H.J., M.P.N. and S.K.K. ; visualization, S.S.A., X.C, V.L. and S.L.S.; supervision, S.S.A. and V.L.; project administration, S.S.A., V.L. and S.K.K.; funding acquisition, S.S.A. and S.K.K. All authors have read and agreed to the published version of the manuscript.

Funding: This research was funded by the Danish Energy Technology Development and Demonstration Program (EUDP) through the projects COBRA Drive (grant number-64018-0118) and Power2Met (grant number-64018-0552).

Conflicts of Interest: The authors declare no conflict of interest. The funders had no role in the design of the study; in the collection, analyses, or interpretation of data; in the writing of the manuscript, or in the decision to publish the results.

\section{References}

1. Shindell, D.; Smith, C.J. Climate and air-quality benefits of a realistic phase-out of fossil fuels. Nature 2019, 573, 408-411, doi:10.1038/s41586-019-1554-z. [CrossRef] [PubMed]

2. Smith, C.J.; Forster, P.M.; Allen, M.; Fuglestvedt, J.; Millar, R.J.; Rogelj, J.; Zickfeld, K. Current fossil fuel infrastructure does not yet commit us to $1.5^{\circ} \mathrm{C}$ warming. Nat. Commun. 2019, 10.10.1038/s41467-018-07999-w. [CrossRef]

3. Shindell, D.; Faluvegi, G.; Seltzer, K.; Shindell, C. Quantified, localized health benefits of accelerated carbon dioxide emissions reductions. Nat. Clim. Chang. 2018, 1-5, doi:10.1038/s41558-018-0108-y. [CrossRef] [PubMed]

4. Weindl, I.; Lotze-Campen, H.; Popp, A.; Müller, C.; Havlík, P.; Herrero, M.; Schmitz, C.; Rolinski, S. Livestock in a changing climate: production system transitions as an adaptation strategy for agriculture. Environ. Res. Lett. 2015, 10, 094021, doi:10.1088/1748-9326. [CrossRef]

5. Lelieveld, J.; Klingmüller, K.; Pozzer, A.; Burnett, R.T.; Haines, A.; Ramanathan, V. Effects of fossil fuel and total anthropogenic emission removal on public health and climate. Proc. Natl. Acad. Sci. USA 2019, 116, 7192-7197, doi:10.1073/pnas.1819989116. [CrossRef]

6. Cohen, A.J.; Brauer, M.; Burnett, R.; Anderson, H.R.; Frostad, J.; Estep, K.; Balakrishnan, K.; Brunekreef, B.; Dandona, L.; Dandona, R.; et al. Estimates and 25-year trends of the global burden of disease attributable to ambient air pollution: an analysis of data from the Global Burden of Diseases Study 2015 . Lancet 2017, 389, 1907-1918, doi:10.1016/S0140-6736(17)30505-6. [CrossRef]

7. IEA. Global Energy \& $\mathrm{CO}_{2}$ Status Report 2019. Available online: https://www.iea.org/reports/globalenergy-and-co2-status-report-2019/emissions (accessed on 17 January 2020).

8. ENERGINET. Rekordlav $\mathrm{CO}_{2}$-udledning fra danskernes elforbrug i 2019. Available online: https:/ / energinet.dk/ Om-nyheder/Nyheder/2020/01/16/Rekord-lav-CO2udledning-fra-danskernes-elforbrug-i-2019 (accessed on 17 January 2020). 
9. Frensch, S.H.; Olesen, A.C.; Simon Araya, S.; Kær, S.K. Model-Supported Analysis of Degradation Phenomena of a PEM Water Electrolysis Cell under Dynamic Operation. ECS Trans. 2018, 85, 37-45, doi:10.1149/08511.0037ecst. [CrossRef]

10. Larscheid, P.; Lück, L.; Moser, A. Potential of new business models for grid integrated water electrolysis. Renew. Energy 2018, 125, 599-608, doi:10.1016/J.RENENE.2018.02.074. [CrossRef]

11. Goldmann, A.; Sauter, W.; Oettinger, M.; Kluge, T.; Schröder, U.; Seume, J.R.; Friedrichs, J.; Dinkelacker, F. A study on electrofuels in aviation. Energies 2018, 11, 1-23, doi:10.3390/en11020392. [CrossRef]

12. Hobson, C.; Márquez, C. Renewable Methanol Report; Technical report; ATA Markets Intelligence S.L. on behalf of the Methanol Institute: Madrid, Spain, 2018.

13. Goeppert, A.; Czaun, M.; Surya Prakash, G.K.; Olah, G.A. Air as the renewable carbon source of the future: An overview of $\mathrm{CO}_{2}$ capture from the atmosphere. Energy Environ. Sci. 2012, 5, 7833-7853, doi:10.1039/c2ee21586a. [CrossRef]

14. Brown, A.; Le Feuvre, P. Technology Roadmap: Delivering Sustainable Bioenergy; International Energy Agency (IEA): Paris, France, 2017; p. 94.

15. Cui, X.; Kær, S.K. Thermodynamic analyses of a moderate-temperature carbon dioxide hydrogenation to methanol via reverse water gas shift process with in situ water removal. Ind. Eng. Chem. Res. 2019.10.1021/acs.iecr.9b01312. [CrossRef]

16. Alberico, E.; Nielsen, M. Towards a methanol economy based on homogeneous catalysis: methanol to $\mathrm{H}_{2}$ and $\mathrm{CO}_{2}$ to methanol. Chem. Commun. 2015, 51, 6714-6725, doi:10.1039/C4CC09471A. [CrossRef] [PubMed]

17. Methanol Institute. Methanol/Methanol Institute. Available online: https://www.methanol.org (accessed on 10 December 2019).

18. Kai Zhao. A Brief Review of China's Methanol Vehicle Pilot and Policy; Technical report; Methanol Institute: Alexandria, VA, USA, 2019.

19. Olah, G.A.; Goeppert, A.; Prakash, G.K.S. Beyond Oil and Gas: The Methanol Economy; Wiley-VCH: Hoboken, NJ, USA, 2006.

20. Olah, G.A. Towards Oil Independence Through Renewable Methanol Chemistry. Angew. Chem. Int. Ed. 2013, 52, 104-107, doi:10.1002/anie.201204995. [CrossRef] [PubMed]

21. Offermanns, H.; Schulz, K.; Brandes, E.; Schendler, T. Methanol Utilisation Technologies. In Methanol: The Basic Chemical and Energy Feedstock of the Future: Asinger's Vision Today; Bertau, M., Offermanns, H., Plass, L., Schmidt, F., Wernicke, H.J., Eds.; Springer: Berlin/Heidelberg, Germany, 2014; pp. 327-601, doi:10.1007/978-3-642-39709-7_5. [CrossRef]

22. Ott, J.; Gronemann, V.; Pontzen, F.; Fiedler, E.; Grossmann, G.; Kersebohm, D.B.; Weiss, G.; Witte, C. Methanol. In Ullmann's Encyclopedia of Industrial Chemistry; Wiley-VCH Verlag GmbH \& Co. KGaA: Weinheim, Germany, 2012; doi:10.1002/14356007.a16_465.pub3. [CrossRef]

23. El-Zeftawy, A.M. Focus on the Chemical Value of Methanol. J. Univ. Eng. Sci. 1995, 7, 209-254, doi:10.1016/S1018-3639(18)31058-4. [CrossRef]

24. Khadzhiev, S.N.; Kolesnichenko, N.V.; Ezhova, N.N. Manufacturing of lower olefins from natural gas through methanol and its derivatives (review). Pet. Chem. 2008, 48, 325-334, doi:10.1134/S0965544108050010. [CrossRef]

25. Zhen, X.; Wang, Y. An overview of methanol as an internal combustion engine fuel. Renew. Sustain. Energy Rev. 2015, 52, 477-493, doi:10.1016/J.RSER.2015.07.083. [CrossRef]

26. Dalena, F.; Senatore, A.; Basile, M.; Knani, S.; Basile, A.; Iulianelli, A. Advances in Methanol Production and Utilization, with Particular Emphasis toward Hydrogen Generation via Membrane Reactor Technology. Membranes 2018, 8, doi:10.3390/membranes8040098. [CrossRef]

27. Alvarado, M. The Changing Face of the Global Methanol Industry; Technical report; IHS: London, UK, 2016.

28. Market Watch. Methanol Market 2019 Analysis and Technological Innovation by Leading Key Players 2026. Available online: https:/ /www.marketwatch.com/press-release/methanol-market-2019-analysisand-technological-innovation-by-leading-key-players-2026-2019-08-07 (accessed on 18 January 2020).

29. Sheldon, D. Methanol Production - A Technical History. Johns. Matthey Technol. Rev. 2017, 61, 172-182, doi:10.1595/205651317X695622. [CrossRef]

30. Bertau, M.; Offermanns, H.; Plass, L.; Schmidt, F.; Wernicke, H.J.; Methanol: The Basic Chemical and Energy Feedstock of the Future: Asinger's Vision Today; Springer: Berlin/Heidelberg, Germany, 2014, doi:10.1007/978-3-642-39709-7. [CrossRef] 
31. Dalena, F.; Senatore, A.; Marino, A.; Gordano, A.; Basile, M.; Basile, A. Chapter 1-Methanol Production and Applications: An Overview. In Methanol; Basile, A., Dalena, F., Eds.; Elsevier: Amsterdam, The Netherlands, 2018; pp. 3-28, doi:10.1016/B978-0-444-63903-5.00001-7. [CrossRef]

32. Wernicke, H.J.; Plass, L.; Schmidt, F. Methanol Generation. In Methanol: The Basic Chemical and Energy Feedstock of the Future: Asinger's Vision Today; Bertau, M., Offermanns, H., Plass, L., Schmidt, F., Wernicke, H.J., Eds.; Springer: Berlin/Heidelberg, Germany, 2014; pp. 51-301, doi:10.1007/978-3-642-39709-7_4. [CrossRef]

33. Rostrup-Nielsen, J.; Christiansen, L.J. Concepts in Syngas Manufacture. In Catalyst Science Series; Imerial Collage Press: London, UK, 2011; Volume 10, p. 379, doi:10.1142/p717. [CrossRef]

34. Cui, X.; Kær, S.K. Two-dimensional thermal analysis of radial heat transfer of monoliths in small-scale steam methane reforming. Int. J. Hydrog. Energy 2018, 43, 11952-11968, doi:10.1016/j.ijhydene.2018.04.142. [CrossRef]

35. Lange, J.P. Methanol synthesis: a short review of technology improvements. Catal. Today 2001, 64, 3-8, doi:10.1016/S0920-5861(00)00503-4. [CrossRef]

36. Bell, D.; Towler, B.; Maohong Fan. Coal Gasification and Its Applications, 1 ed.; Elsevier Ltd.: Amsterdam, The Netherlands, 2011; p. 416, doi:10.1016/C2009-0-20067-5. [CrossRef]

37. Liu, K.; Song, C.; Subramani, V. Hydrogen and Syngas Production and Purification Technologies; John Wiley \& Sons: Hoboken, NJ, USA, 2009; pp. 1-533.10.1002/9780470561256. [CrossRef]

38. Bozzano, G.; Manenti, F. Efficient methanol synthesis: Perspectives, technologies and optimization strategies. Prog. Energy Combust. Sci. 2016, 56, 71-105, doi:10.1016/J.PECS.2016.06.001. [CrossRef]

39. Barbieri, G.; Marigliano, G.; Golemme, G.; Drioli, E. Simulation of $\mathrm{CO}_{2}$ hydrogenation with $\mathrm{CH}_{3} \mathrm{OH}$ removal in a zeolite membrane reactor. Chem. Eng. J. 2002, 85, 53-59, doi:10.1016/S1385-8947(01)00143-7. [CrossRef]

40. Riaz, A.; Zahedi, G.; Klemeš, J.J. A review of cleaner production methods for the manufacture of methanol. J. Clean. Prod. 2013, 57, 19-37, doi:10.1016/j.jclepro.2013.06.017. [CrossRef]

41. Palma, V.; Meloni, E.; Ruocco, C.; Martino, M.; Ricca, A. State of the Art of Conventional Reactors for Methanol Production. In Methanol Science and Engineering; Angelo, B., Francesco, D., Eds.; Elsevier: Amsterdam, The Netherlands, 2018; pp. 29-51, doi:10.1016/B978-0-444-63903-5.00002-9. [CrossRef]

42. Blug, M.; Leker, J.; Plass, L.; Günther, A. Methanol Generation Economics. In Methanol: The Basic Chemical and Energy Feedstock of the Future: Asinger's Vision Today; Bertau, M., Offermanns, H., Plass, L., Schmidt, F., Wernicke, H.J., Eds.; Springer: Berlin, Germany, 2014; pp. 603-618, doi:10.1007/978-3-642-39709-7_7. [CrossRef]

43. Dahl, P.J.; Ostergaard, J. Process for Production of DME from Crude Methanol. U.S. Patent 10,011,548, 3 July 2018.

44. Isayama, Y.; Saka, S. Biodiesel production by supercritical process with crude bio-methanol prepared by wood gasification. Bioresour. Technol. 2008, 99, 4775-4779, doi:10.1016/j.biortech.2007.09.056. [CrossRef] [PubMed]

45. Zhang, J.; Liang, S.; Feng, X. A novel multi-effect methanol distillation process. Chem. Eng. Process. Process. Intensif. 2010, 49, 1031-1037, doi:10.1016/J.CEP.2010.07.003. [CrossRef]

46. Cui, C.; Xi, Z.; Liu, S.; Sun, J. An enumeration-based synthesis framework for multi-effect distillation processes. Chem. Eng. Res. Des. 2019, 144, 216-227, doi:10.1016/J.CHERD.2019.02.018. [CrossRef]

47. Cui, C.; Sun, J.; Li, X. A hybrid design combining double-effect thermal integration and heat pump to the methanol distillation process for improving energy efficiency. Chem. Eng. Process. Process. Intensif. 2017, 119, 81-92, doi:10.1016/J.CEP.2017.06.003. [CrossRef]

48. Gahleitner, G. Hydrogen from renewable electricity: An international review of power-to-gas pilot plants for stationary applications. Int. J. Hydrog. Energy 2013, 38, 2039-2061, doi:10.1016/J.IJHYDENE.2012.12.010. [CrossRef]

49. Bui, M.; Adjiman, C.S.; Bardow, A.; Anthony, E.J.; Boston, A.; Brown, S.; Fennell, P.S.; Fuss, S.; Galindo, A.; Hackett, L.A.; et al. Carbon capture and storage (CCS): The way forward. Energy Environ. Sci. 2018, 11, 1062-1176, doi:10.1039/c7ee02342a. [CrossRef]

50. Serenergy A/S. Methanol Production. Available online: http://www.serenergy.com (accessed on 10 December 2019).

51. Marlin, D.S.; Sarron, E.; Sigurbjörnsson, Ó. Process Advantages of Direct CO2 to Methanol Synthesis. Front. Chem. 2018, 6, 1-8, doi:10.3389/fchem.2018.00446. [CrossRef] 
52. Gallucci, F.; Paturzo, L.; Basile, A. An experimental study of $\mathrm{CO}_{2}$ hydrogenation into methanol involving a zeolite membrane reactor. Chem. Eng. Process. Process. Intensif. 2004, 43, 1029-1036, doi:10.1016/J.CEP.2003.10.005. [CrossRef]

53. Dehghani, Z.; Bayat, M.; Rahimpour, M. Sorption-enhanced methanol synthesis: Dynamic modeling and optimization. J. Taiwan Inst. Chem. Eng. 2014, 45, 1490-1500, doi:10.1016/J.JTICE.2013.12.001. [CrossRef]

54. Arora, A.; Iyer, S.S.; Bajaj, I.; Faruque Hasan, M.M. Optimal Methanol Production via Sorption-Enhanced Reaction Process. Ind. Eng. Chem. Res. 2018, 57, 14143-14161, doi:10.1021/acs.iecr.8b02543. [CrossRef]

55. Bos, M.; Brilman, D. A novel condensation reactor for efficient $\mathrm{CO}_{2}$ to methanol conversion for storage of renewable electric energy. Chem. Eng. J. 2015, 278, 527-532, doi:10.1016/J.CEJ.2014.10.059. [CrossRef]

56. Bukhtiyarova, M.; Lunkenbein, T.; Kähler, K.; Schlögl, R. Methanol Synthesis from Industrial $\mathrm{CO}_{2} \mathrm{Sources}_{\mathrm{A}}$ Contribution to Chemical Energy Conversion. Catal. Lett. 2017, 147, 416-427, doi:10.1007/s10562-016-1960-x. [CrossRef]

57. Liu, X.M.; Lu, G.Q.; Yan, Z.F.; Beltramini, J. Recent Advances in Catalysts for Methanol Synthesis via Hydrogenation of $\mathrm{CO}$ and $\mathrm{CO}_{2}$. Ind. Eng. Chem. Res. 2003, 42, 6518-6530, doi:10.1021/ie020979s. [CrossRef]

58. Saeidi, S.; Amin, N.A.S.; Rahimpour, M.R. Hydrogenation of $\mathrm{CO}_{2}$ to value-added products-A review and potential future developments. J. CO2 Util. 2014, 5, 66-81, doi:10.1016/J.JCOU.2013.12.005. [CrossRef]

59. Ganesh, I. Conversion of carbon dioxide into methanol-A potential liquid fuel: Fundamental challenges and opportunities (a review). Renew. Sustain. Energy Rev. 2014, 31, 221-257, doi:10.1016/J.RSER.2013.11.045. [CrossRef]

60. Jadhav, S.G.; Vaidya, P.D.; Bhanage, B.M.; Joshi, J.B. Catalytic carbon dioxide hydrogenation to methanol: A review of recent studies. Chem. Eng. Res. Des. 2014, 92, 2557-2567, doi:10.1016/J.CHERD.2014.03.005. [CrossRef]

61. Dang, S.; Yang, H.; Gao, P.; Wang, H.; Li, X.; Wei, W.; Sun, Y. A review of research progress on heterogeneous catalysts for methanol synthesis from carbon dioxide hydrogenation. Catal. Today 2019, 330, 61-75.10.1016/J.CATTOD.2018.04.021. [CrossRef]

62. Roy, S.; Cherevotan, A.; Peter, S.C. Thermochemical $\mathrm{CO}_{2}$ Hydrogenation to Single Carbon Products: Scientific and Technological Challenges. ACS Energy Lett. 2018, 3, 1938-1966, doi:10.1021/acsenergylett.8b00740. [CrossRef]

63. Pontzen, F.; Liebner, W.; Gronemann, V.; Rothaemel, M.; Ahlers, B. $\mathrm{CO}_{2}$-based methanol and DME - Efficient technologies for industrial scale production. Catal. Today 2011, 171, 242-250, doi:10.1016/j.cattod.2011.04.049. [CrossRef]

64. Joo, O.S.; Jung, K.D.; Moon, I.; Rozovskii, A.Y.; Lin, G.I.; Han, S.H.; Uhm, S.J. Carbon dioxide hydrogenation to form methanol via a reverse-water-gas- shift reaction (the CAMERE process). Ind. Eng. Chem. Res. 1999, 38, 1808-1812, doi:10.1021/ie9806848. [CrossRef]

65. Joo, O.S.; Jung, K.D.; Yonsoo, J. CAMERE Process for methanol synthesis from $\mathrm{CO}_{2}$ hydrogenation. Stud. Surf. Sci. Catal. 2004, 153, 67-72, doi:10.1016/S0167-2991(04)80221-0. [CrossRef]

66. Anicic, B.; Trop, P.; Goricanec, D. Comparison between two methods of methanol production from carbon dioxide. Energy 2014, 77, 279-289, doi:10.1016/J.ENERGY.2014.09.069. [CrossRef]

67. Samimi, F.; Rahimpour, M.R. Direct Methanol Fuel Cell. In Methanol Science and Engineering; Basile, A., Dalena, F., Eds.; Elsevier: Amsterdam, The Netherlands, 2018; pp. 381-397, doi:10.1016/B978-0-444-63903-5.00014-5. [CrossRef]

68. Zheng, Y.; Wang, J.; Yu, B.; Zhang, W.; Chen, J.; Qiao, J.; Zhang, J. A review of high temperature co-electrolysis of $\mathrm{H}_{2} \mathrm{O}$ and $\mathrm{CO}_{2}$ to produce sustainable fuels using solid oxide electrolysis cells (SOECs): Advanced materials and technology. Chem. Soc. Rev. 2017, 46, 1427-1463, doi:10.1039/c6cs00403b. [CrossRef]

69. Graves, C.; Ebbesen, S.D.; Mogensen, M. Co-electrolysis of $\mathrm{CO}_{2}$ and $\mathrm{H}_{2} \mathrm{O}$ in solid oxide cells: Performance and durability. Solid State Ionics 2011, 192, 398-403, doi:10.1016/J.SSI.2010.06.014. [CrossRef]

70. Andika, R.; Nandiyanto, A.B.D.; Putra, Z.A.; Bilad, M.R.; Kim, Y.; Yun, C.M.; Lee, M. Co-electrolysis for power-to-methanol applications. Renew. Sustain. Energy Rev. 2018, 95, 227-241.10.1016/J.RSER.2018.07.030. [CrossRef]

71. Jensen, S.H.; Graves, C.; Chen, M.; Hansen, J.B.; Sun, X. Characterization of a planar solid oxide cell stack operated at elevated pressure. J. Electrochem. Soc. 2016, 163, F1596-F1604.10.1149/2.1171614jes. [CrossRef] 
72. Al-Kalbani, H.; Xuan, J.; García, S.; Wang, H. Comparative energetic assessment of methanol production from CO2: Chemical versus electrochemical process. Appl. Energy 2016, 165, 1-13, doi:10.1016/j.apenergy.2015.1. [CrossRef]

73. Sun, X.; Chen, M.; Jensen, S.H.; Ebbesen, S.D.; Graves, C.; Mogensen, M. Thermodynamic analysis of synthetic hydrocarbon fuel production in pressurized solid oxide electrolysis cells. Int. J. Hydrog. Energy 2012, 37, 17101-17110, doi:10.1016/j.ijhydene.2012.08.125. [CrossRef]

74. Ebbesen, S.D.; Hansen, J.B.; Mogensen, M.B. Biogas upgrading using SOEC with a Ni-ScYSZ electrode. In ECS Transactions; Electrochemical Society Inc.: Pennington, NJ, USA, 2013; Volume 57, pp. 3217-3227, doi:10.1149/05701.3217ecst. [CrossRef]

75. Yoneima, T.; Fukushima, K.; Saito, N.; Nakashima, K. Effect of Sulfur on the Sintering of Nickel Particles. Mater. Trans. 2016, 57, 1374-1377, doi:10.2320/matertrans.M2015464. [CrossRef]

76. Brett, D.J.L.; Atkinson, A.; Cumming, D.; Ramírez-Cabrera, E.; Rudkin, R.; Brandon, N.P. Methanol as a direct fuel in intermediate temperature $\left(500-600{ }^{\circ} \mathrm{C}\right)$ solid oxide fuel cells with copper based anodes. Chem. Eng. Sci. 2005, 60, 5649-5662, doi:10.1016/j.ces.2005.05.030. [CrossRef]

77. Skafte, T.L.; Guan, Z.; Machala, M.L.; Gopal, C.B.; Monti, M.; Martinez, L.; Stamate, E.; Sanna, S.; Garrido Torres, J.A.; Crumlin, E.J.; et al. Selective high-temperature CO2 electrolysis enabled by oxidized carbon intermediates. Nat. Energy 2019, 4, 846-855, doi:10.1038/s41560-019-0457-4. [CrossRef]

78. Saito, M.; Takeuchi, M.; Fujitani, T.; Toyir, J.; Luo, S.; Wu, J.; Mabuse, H.; Ushikoshi, K.; Mori, K.; Watanabe, T. Advances in joint research between NIRE and RITE for developing a novel technology for methanol synthesis from CO2 and H2. Appl. Organomet. Chem. 2000, 14, 763-772, doi:10.1002/1099-0739(200012)14:12<763::AID-AOC98>3.0.CO;2-4. [CrossRef]

79. Toyir, J.; Miloua, R.; Elkadri, N.; Nawdali, M.; Toufik, H.; Miloua, F.; Saito, M. Sustainable process for the production of methanol from $\mathrm{CO}_{2}$ and $\mathrm{H}_{2}$ using $\mathrm{Cu} / \mathrm{ZnO}$-based multicomponent catalyst. Phys. Procedia 2009, 2, 1075-1079, doi:10.1016/J.PHPRO.2009.11.065. [CrossRef]

80. Doss, B.; Ramos, C.; Atkins, S. Optimization of Methanol Synthesis from Carbon Dioxide and Hydrogen: Demonstration of a Pilot-Scale Carbon-Neutral Synthetic Fuels Process. Energy Fuels 2009, 23, 4647-4650, doi:10.1021/ef900466u. [CrossRef]

81. Deerberg, G.; Oles, M.; Schlögl, R. The Project Carbon2Chem®®. Chemie-Ingenieur-Technik 2018, 90, 1365-1368, doi:10.1002/cite.201800060. [CrossRef]

82. Power2Met. Available online: https:/ / energiforskning.dk/en/node/9313 (accessed on 10 December 2019).

83. Brynolf, S.; Taljegard, M.; Grahn, M.; Hansson, J. Electrofuels for the transport sector: A review of production costs. Renew. Sustain. Energy Rev. 2018, 81, 1887-1905, doi:10.1016/j.rser.2017.05.288. [CrossRef]

84. Klenert, D.; Mattauch, L.; Combet, E.; Edenhofer, O.; Hepburn, C.; Rafaty, R.; Stern, N. Making carbon pricing work for citizens. Nat. Clim. Chang. 2018, 8, 669-677, doi:10.1038/s41558-018-0201-2. [CrossRef]

85. Ramstein, C.; Dominioni, G.; Ettehad, S.; Lam, L.; Quant, M.; Zhang, J.; Mark, L.; Nierop, S.; Berg, T.; Leuschner, P.; et al. State and Trends of Carbon Pricing 2019; The World Bank: Washington, DC, USA, 2019, doi:10.1596/978-1-4648-1435-8. [CrossRef]

86. Laude, A.; Ricci, O.; Bureau, G.; Royer-Adnot, J.; Fabbri, A. $\mathrm{CO}_{2}$ capture and storage from a bioethanol plant: Carbon and energy footprint and economic assessment. Int. J. Greenh. Gas Control. 2011, 5, 1220-1231, doi:10.1016/J.IJGGC.2011.06.004. [CrossRef]

87. Lin, W.C.; Chen, Y.P.; Tseng, C.P. Pilot-scale chemical-biological system for efficient $\mathrm{H}_{2} \mathrm{~S}$ removal from biogas. Bioresour. Technol. 2013, 135, 283-291, doi:10.1016/J.BIORTECH.2012.10.040. [CrossRef] [PubMed]

88. Bao, Z.; Yu, F. Catalytic Conversion of Biogas to Syngas via Dry Reforming Process. Adv. Bioenergy 2018, 3, 43-76, doi:10.1016/BS.AIBE.2018.02.002. [CrossRef]

89. Kumar, N.; Shojaee, M.; Spivey, J.J. Catalytic bi-reforming of methane: From greenhouse gases to syngas. Curr. Opin. Chem. Eng. 2015, 9, 8-15, doi:10.1016/j.coche.2015.07.003. [CrossRef]

90. Hansen, J.B.; Fock, F.; Lindboe, H.H. Biogas upgrading: By steam electrolysis or co-electrolysis of biogas and steam? ECS Trans. 2013, 57, 3089-3097, doi:10.1149/05701.3089ecst. [CrossRef]

91. International Energy Agency (IEA). Technology Roadmap: Carbon Capture and Storage; Technical report; IEA: Paris, France, 2013.

92. Odeh, N.A.; Cockerill, T.T. Life cycle GHG assessment of fossil fuel power plants with carbon capture and storage. Energy Policy 2008, 36, 367-380, doi:10.1016/J.ENPOL.2007.09.026. [CrossRef] 
93. Leung, D.Y.; Caramanna, G.; Maroto-Valer, M.M. An overview of current status of carbon dioxide capture and storage technologies. Renew. Sustain. Energy Rev. 2014, 39, 426-443, doi:10.1016/J.RSER.2014.07.093. [CrossRef]

94. Pérez-Fortes, M.; Schöneberger, J.C.; Boulamanti, A.; Tzimas, E. Methanol synthesis using captured $\mathrm{CO}_{2}$ as raw material: Techno-economic and environmental assessment. Appl. Energy 2016, 161, 718-732, doi:10.1016/J.APENERGY.2015.07.067. [CrossRef]

95. Holloway, S. Safety of the underground disposal of carbon dioxide. Energy Convers. Manag. 1997, 38, S241-S245, doi:10.1016/S0196-8904(96)00276-2. [CrossRef]

96. Ehteshami, S.M.M.; Chan, S.H. The role of hydrogen and fuel cells to store renewable energy in the future energy network - potentials and challenges. Energy Policy 2014, 73, 103-109, doi:10.1016/j.enpol.2014.04.046. [CrossRef]

97. Barbir, F. PEM electrolysis for production of hydrogen from renewable energy sources. Solar Energy 2005, 78, 661-669, doi:10.1016/j.solener.2004.09.003. [CrossRef]

98. Kiaee, M.; Cruden, A.; Infield, D.; Chladek, P. Improvement of power system frequency stability using alkaline electrolysis plants. Proc. Inst. Mech. Eng. Part J. Power Energy 2013, 227, 115-123.10.1177/0957650912466642. [CrossRef]

99. Guinot, B.; Montignac, F.; Champel, B.; Vannucci, D. Profitability of an electrolysis based hydrogen production plant providing grid balancing services. Int. J. Hydrog. Energy 2015, 40, 8778-8787.10.1016/J.IJHYDENE.2015.05.033. [CrossRef]

100. Mohammadi, A.; Mehrpooya, M. A comprehensive review on coupling different types of electrolyzer to renewable energy sources. Energy 2018, 158, 632-655, doi:10.1016/J.ENERGY.2018.06.073. [CrossRef]

101. Sherif, S.; Barbir, F.; Veziroglu, T. Wind energy and the hydrogen economy-Review of the technology. Solar Energy 2005, 78, 647-660, doi:10.1016/J.SOLENER.2005.01.002. [CrossRef]

102. Bellotti, D.; Rivarolo, M.; Magistri, L.; Massardo, A. Thermo-economic comparison of hydrogen and hydro-methane produced from hydroelectric energy for land transportation. Int. J. Hydrog. Energy 2015, 40, 2433-2444, doi:10.1016/J.IJHYDENE.2014.12.066. [CrossRef]

103. Yilmaz, F.; Ozturk, M.; Selbas, R. Thermodynamic performance assessment of ocean thermal energy conversion based hydrogen production and liquefaction process. Int. J. Hydrog. Energy 2018, 43, 10626-10636, doi:10.1016/J.IJHYDENE.2018.02.021. [CrossRef]

104. Khosravi, A.; Syri, S.; Assad, M.; Malekan, M. Thermodynamic and economic analysis of a hybrid ocean thermal energy conversion/photovoltaic system with hydrogen-based energy storage system. Energy 2019, 172, 304-319, doi:10.1016/J.ENERGY.2019.01.100. [CrossRef]

105. Balta, M.T.; Hepbasli, A. Potential methods for geothermal-based hydrogen production. Int. J. Hydrog. Energy 2010, 35, 4949-4961, doi:10.1016/J.IJHYDENE.2009.09.040. [CrossRef]

106. Tolga Balta, M.; Dincer, I.; Hepbasli, A. Thermodynamic assessment of geothermal energy use in hydrogen production. Int. J. Hydrog. Energy 2009, 34, 2925-2939, doi:10.1016/J.IJHYDENE.2009.01.087. [CrossRef]

107. Acar, C.; Dincer, I. Comparative assessment of hydrogen production methods from renewable and non-renewable sources. Int. J. Hydrog. Energy 2014, 39, 1-12, doi:10.1016/j.ijhydene.2013.10.060. [CrossRef]

108. Mori, D.; Hirose, K. Recent challenges of hydrogen storage technologies for fuel cell vehicles. Int. J. Hydrog. Energy 2009, 34, 4569-4574, doi:10.1016/J.IJHYDENE.2008.07.115. [CrossRef]

109. Acar, C.; Dincer, I. Review and evaluation of hydrogen production options for better environment. J. Clean. Prod. 2019, 218, 835-849, doi:10.1016/j.jclepro.2019.02.046. [CrossRef]

110. Nikolaidis, P.; Poullikkas, A. A comparative overview of hydrogen production processes. Renew. Sustain. Energy Rev. 2017, 67, 597-611, doi:10.1016/j.rser.2016.09.044. [CrossRef]

111. Ramea, K. An integrated quantitative-qualitative study to monitor the utilization and assess the perception of hydrogen fueling stations. Int. J. Hydrog. Energy 2019, doi:10.1016/j.ijhydene.2019.05.053. [CrossRef]

112. Santos, D.M.; Sequeira, C.A.; Figueiredo, J.L. Hydrogen production by alkaline water electrolysis. Quimica Nova 2013, 36, 1176-1193, doi:10.1590/S0100-40422013000800017. [CrossRef]

113. Kreuter, W.; Hofmann, H. Electrolysis: The important energy transformer in a world of sustainable energy. Int. J. Hydrog. Energy 1998, 23, 661-666, doi:10.1016/S0360-3199(97)00109-2. [CrossRef]

114. Feng, Q.; Yuan, X.Z.; Liu, G.; Wei, B.; Zhang, Z.; Li, H.; Wang, H. A review of proton exchange membrane water electrolysis on degradation mechanisms and mitigation strategies. J. Power Sour. 2017, 366, 33-55, doi:10.1016/j.jpowsour.2017.09.006. [CrossRef] 
115. Rashid, M.; Al Mesfer, M.K.; Naseem, H.; Danish, M. Hydrogen Production by Water Electrolysis: A Review of Alkaline Water Electrolysis, PEM Water Electrolysis and High Temperature Water Electrolysis. Int. J. Eng. Adv. Technol. (IJEAT) 2015, 4, 2249-8958.

116. Ursúa, A.; Gandía, L.M.; Sanchis, P. Hydrogen production from water electrolysis: Current status and future trends. Proc. IEEE 2012, 100, 410-426, doi:10.1109/JPROC.2011.2156750. [CrossRef]

117. Götz, M.; Lefebvre, J.; Mörs, F.; McDaniel Koch, A.; Graf, F.; Bajohr, S.; Reimert, R.; Kolb, T. Renewable Power-to-Gas: A technological and economic review. Renew. Energy 2016, 85, 1371-1390, doi:10.1016/j.renene.2015.07.066. [CrossRef]

118. David, M.; Ocampo-Martínez, C.; Sánchez-Peña, R. Advances in alkaline water electrolyzers: A review. J. Energy Storage 2019, 23, 392-403, doi:10.1016/j.est.2019.03.001. [CrossRef]

119. Chisholm, G.; Cronin, L. Hydrogen From Water Electrolysis. In Storing Energy: With Special Reference to Renewable Energy Sources; Elsevier Inc.: Amsterdam, The Netherlands, 2016; pp. 315-343, doi:10.1016/B978-0-12-803440-8.00016-6. [CrossRef]

120. Carmo, M.; Fritz, D.L.; Mergel, J.; Stolten, D. A comprehensive review on PEM water electrolysis. Int. J. Hydrog. Energy 2013, 38, 4901-4934, doi:10.1016/j.ijhydene.2013.01.151. [CrossRef]

121. Marshall, A.; Børresen, B.; Hagen, G.; Tsypkin, M.; Tunold, R. Hydrogen production by advanced proton exchange membrane (PEM) water electrolysers-Reduced energy consumption by improved electrocatalysis. Energy 2007, 32, 431-436, doi:10.1016/j.energy.2006.07.014. [CrossRef]

122. Al Shakhshir, S.; Cui, X.; Frensch, S.; Kær, S.K. In-situ experimental characterization of the clamping pressure effects on low temperature polymer electrolyte membrane electrolysis. Int. J. Hydrog. Energy 2017, 42, 21597-21606, doi:10.1016/J.IJHYDENE.2017.07.059. [CrossRef]

123. Li, N.; Araya, S.S.; Kær, S.K. The effect of $\mathrm{Fe}_{3}{ }^{+}$contamination in feed water on proton exchange membrane electrolyzer performance. Int. J. Hydrog. Energy 2019, 44, 12952-12957, doi:10.1016/j.ijhydene.2019.04.015. [CrossRef]

124. Slavcheva, E.; Radev, I.; Bliznakov, S.; Topalov, G.; Andreev, P.; Budevski, E. Sputtered iridium oxide films as electrocatalysts for water splitting via PEM electrolysis. Electrochim. Acta 2007, 52, 3889-3894, doi:10.1016/j.electacta.2006.11.005. [CrossRef]

125. Slavcheva, E.; Borisov, G.; Lefterova, E.; Petkucheva, E.; Boshnakova, I. Ebonex supported iridium as anode catalyst for PEM water electrolysis. Int. J. Hydrog. Energy 2015, 40, 11356-11361.10.1016/j.ijhydene.2015.03.005. [CrossRef]

126. Paulose, M.; Mor, G.K.; Varghese, O.K.; Shankar, K.; Grimes, C.A. Visible light photoelectrochemical and water-photoelectrolysis properties of titania nanotube arrays. J. Photochem. Photobiol. Chem. 2006, 178, 8-15, doi:10.1016/J.JPHOTOCHEM.2005.06.013. [CrossRef]

127. Lindquist, S.E.; Fell, C. Fuels-Hydrogen Generators I Photoelectrolysis. Encycl. Electrochem. Power Sources 2009, 369-383, doi:10.1016/B978-044452745-5.00319-1. [CrossRef]

128. Ahmed, M.; Dincer, I. A review on photoelectrochemical hydrogen production systems: Challenges and future directions. Int. J. Hydrog. Energy 2019, 44, 2474-2507, doi:10.1016/J.IJHYDENE.2018.12.037. [CrossRef]

129. Ausfelder, F.; Beilmann, C; Bertau, M.; Bräuninger, S.; Heinzel, A.; Hoer, R.; Koch, W.; Mahlendorf, F.; Metzelthin, A.; Peuckert, M.; et al. Energy Storage as Part of a Secure Energy Supply. ChemBioEng Reviews 2017, 4, 144-210, doi:10.1002/cben.201700004. [CrossRef]

130. Verhelst, S.; Turner, J.W.; Sileghem, L.; Vancoillie, J. Methanol as a fuel for internal combustion engines. Prog. Energy Combust. Sci. 2019, 70, 43-88, doi:10.1016/J.PECS.2018.10.001. [CrossRef]

131. Methanol as a Vehicle Fuel | Methanex Corporation. Available online: https://www.methanex.com/aboutmethanol/methanol-vehicle-fuel (accessed on 10 December 2019).

132. Gavaghan, H. Technology: California cleans up its cars with methanol INew Scientist. Available online: https:/ / www.newscientist.com/article/mg12517073-900-technology-california-cleansup-its-cars-with-methanol/ (accessed on 25 January 2020).

133. Fuel freedom foundation. When California had 15,000 methanol cars-Fuel Freedom Foundation. Available online: https://www.fuelfreedom.org/when-california-had-15000-methanol-cars / (accessed on 10 December 2019).

134. International Maritime Organization (IMO). Sulphur 2020-Cutting Sulphur Oxide Emissions. Available online: http:/ /www.imo.org/en/MediaCentre/HotTopics/Pages/Sulphur-2020.aspx (accessed on 10 December 2019) 
135. International Maritime Organization (IMO). Energy efficiency and the reduction of GHG emissions from ships. Available online: http://www.imo.org/en/MediaCentre/HotTopics/GHG/Pages/default.aspx (accessed on 10 December 2019)

136. Gregory Dolan. Overview of Global Methanol Fuel Blending; Technical report; Methanol Institute: Alexandria, VA, USA, 2019.

137. A.P. Moller - Maersk and Lloyds Register. Alcohol, Biomethane and Ammonia are the best-positioned fuels to reach zero net emissions. Available online: https://www.maersk.com/news/articles/2019/10/24/ alcohol-biomethane-and-ammonia-are-the-best-positioned-fuels-to-reach-zero-net-emissions (accessed on 10 December 2019)

138. Transport \& Environment (TE). Roadmap to Decarbonising European Aviation; Technical report; European Federation for Transport \& Environment AISBL: Brussels, Belgium, 2018.

139. Mekhilef, S.; Saidur, R.; Safari, A. Comparative study of different fuel cell technologies. Renew. Sustain. Energy Rev. 2012, 16, 981-989, doi:10.1016/j.rser.2011.09.020. [CrossRef]

140. Kamarudin, S.; Achmad, F.; Daud, W. Overview on the application of direct methanol fuel cell (DMFC) for portable electronic devices. Int. J. Hydrog. Energy 2009, 34, 6902-6916, doi:10.1016/J.IJHYDENE.2009.06.013. [CrossRef]

141. Icardi, U.; Specchia, S.; Fontana, G.; Saracco, G.; Specchia, V. Compact direct methanol fuel cells for portable application. J. Power Sour. 2008, 176, 460-467, doi:10.1016/j.jpowsour.2007.08.048. [CrossRef]

142. Kang, K.; Park, S.; Cho, S.O.; Choi, K.; Ju, H. Development of Lightweight 200-W Direct Methanol Fuel Cell System for Unmanned Aerial Vehicle Applications and Flight Demonstration. Fuel Cells 2014, 14, 694-700, doi:10.1002/fuce.201300244. [CrossRef]

143. Gong, A.; Verstraete, D. Fuel cell propulsion in small fixed-wing unmanned aerial vehicles: Current status and research needs. Int. J. Hydrog. Energy 2017, 42, 21311-21333, doi:10.1016/j.ijhydene.2017.06.148. [CrossRef]

144. González-Espasandín, Ó.; Leo, T.J.; Navarro-Arévalo, E. Fuel cells: A real option for unmanned aerial vehicles propulsion. Sci. World J. 2014, 2014, doi:10.1155/2014/497642. [CrossRef]

145. SerEnergy A/S. The Benefits of Methanol Fuel Cells. Available online: https://serenergy.com/ (accessed on 10 December 2019).

146. Lotrič, A.; Sekavčnik, M.; Hočevar, S. Effectiveness of heat-integrated methanol steam reformer and polymer electrolyte membrane fuel cell stack systems for portable applications. J. Power Sour. 2014, 270, 166-182, doi:10.1016/j.jpowsour.2014.07.072. [CrossRef]

147. Ribeirinha, P.; Alves, I.; Vázquez, F.V.; Schuller, G.; Boaventura, M.; Mendes, A. Heat integration of methanol steam reformer with a high-temperature polymeric electrolyte membrane fuel cell. Energy 2017, 120, 468-477, doi:10.1016/j.energy.2016.11.101. [CrossRef]

148. Thomas, S.; Araya, S.S.; Frensch, S.H.; Steenberg, T.; Kær, S.K. Hydrogen mass transport resistance changes in a high temperature polymer membrane fuel cell as a function of current density and acid doping. Electrochim. Acta 2019, 317, 521-527, doi:10.1016/j.electacta.2019.06.021. [CrossRef]

149. Andreasen, S.J.; Kær, S.K.; Justesen, K.K.; Sahlin, S.L. High Temperature PEM Fuel Cell Systems, Control and Diagnostics. In High Temperature Polymer Electrolyte Membrane Fuel Cells; Springer International Publishing: Cham, Switzerland, 2016; pp. 459-486, doi:10.1007/978-3-319-17082-4_21. [CrossRef]

150. Araya, S.S.; Zhou, F.; Liso, V.; Sahlin, S.L.; Vang, J.R.; Thomas, S.; Gao, X.; Jeppesen, C.; Kær, S.K. A comprehensive review of PBI-based high temperature PEM fuel cells. Int. J. Hydrog. Energy 2016, 41, 21310-21344, doi:10.1016/j.ijhydene.2016.09.024. [CrossRef]

151. Andreasen, S.J. Design and Control of High Temperature PEM Fuel Cell System. Ph.D. Thesis, Aalborg University, Aalborg, Denmark, 2009.

152. Kurz, T.; Küfner, F.; Gerteisen, D. Heating of Low and High Temperature PEM Fuel Cells with Alternating Current. Fuel Cells 2018, 18, 326-334, doi:10.1002/fuce.201700145. [CrossRef]

153. Geissler, K.; Newson, E.; Vogel, F.; Truong, T.B.; Hottinger, P.; Wokaun, A. Autothermal methanol reforming for hydrogen production in fuel cell applications. Phys. Chem. Chem. Phys. 2001, 3, 289-293, doi:10.1039/b004881j. [CrossRef]

154. Iulianelli, A.; Ribeirinha, P.; Mendes, A.; Basile, A. Methanol steam reforming for hydrogen generation via conventional and membrane reactors: A review. Renew. Sustain. Energy Rev. 2014, 29, 355-368, doi:10.1016/j.rser.2013.08.032. [CrossRef] 
155. Karim, A.; Bravo, J.; Gorm, D.; Conant, T.; Datye, A. Comparison of wall-coated and packed-bed reactors for steam reforming of methanol. Catal. Today 2005, 110, 86-91, doi:10.1016/j.cattod.2005.09.010. [CrossRef]

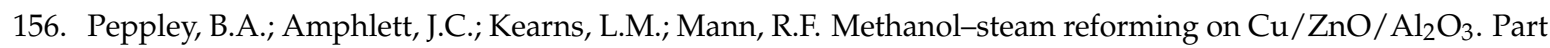
1: the reaction network. Appl. Catal. Gen. 1999, 179, 21-29, doi:10.1016/S0926-860X(98)00298-1. [CrossRef]

157. Peppley, B.A.; Amphlett, J.C.; Kearns, L.M.; Mann, R.F. Methanol-steam reforming on $\mathrm{Cu} / \mathrm{ZnO} / \mathrm{Al}_{2} \mathrm{O}_{3}$ catalysts. Part 2. A comprehensive kinetic model. Appl. Catal. Gen. 1999, 179, 31-49.10.1016/S0926-860X(98)00299-3. [CrossRef]

158. Papavasiliou, J.; Avgouropoulos, G.; Ioannides, T. Steady-state isotopic transient kinetic analysis of steam reforming of methanol over Cu-based catalysts. Appl. Catal. Environ. 2009, 88, 490-496, doi:10.1016/j.apcatb.2008.10.018. [CrossRef]

159. Huang, C.Y.; Sun, Y.M.; Chou, C.Y.; Su, C.C. Performance of catalysts $\mathrm{CuO}-\mathrm{ZnO}_{\mathrm{n}}-\mathrm{Al}_{2} \mathrm{O}_{3}$, $\mathrm{CuO}-\mathrm{ZnO}-\mathrm{Al}_{2} \mathrm{O}_{3}-\mathrm{Pt}-\mathrm{Rh}$, and $\mathrm{Pt}-\mathrm{Rh}$ in a small reformer for hydrogen generation. J. Power Sour. 2007, 166, 450-457. [CrossRef]

160. Purnama, H.; Ressler, T.; Jentoft, R.E.; Soerijanto, H.; Schlögl, R.; Schomäcker, R. CO formation/selectivity for steam reforming of methanol with a commercial $\mathrm{CuO} / \mathrm{ZnO} / \mathrm{Al}_{2} \mathrm{O}_{3}$ catalyst. Appl. Catal. Gen. 2004, 259, 83-94, doi:10.1016/j.apcata.2003.09.013. [CrossRef]

161. Sahlin, S.L. Characterization and Modeling of a Methanol Reforming Fuel Cell System. Ph.D. Thesis, Aalborg University, Aalborg, Denmark, 2016; doi:10.5278/vbn.phd.engsci.00059. [CrossRef]

162. Simon Araya, S.; Juhl Andreasen, S.; Venstrup Nielsen, H.; Knudsen Kær, S. Investigating the effects of methanol-water vapor mixture on a PBI-based high temperature PEM fuel cell. Int. J. Hydrog. Energy 2012, 37, 18231-18242. [CrossRef]

163. Sá, S.; Silva, H.; Brandão, L.; Sousa, J.M.; Mendes, A. Catalysts for methanol steam reforming-A review. Appl. Catal. Environ. 2010, 99, 43-57, doi:10.1016/j.apcatb.2010.06.015. [CrossRef]

164. Palo, D.R.; Dagle, R.A.; Holladay, J.D. Methanol Steam Reforming for Hydrogen Production. Chem. Rev. 2007, 107, 3992-4021, doi:10.1021/cr050198b. [CrossRef] [PubMed]

165. Twigg, M.V.; Spencer, M.S. Deactivation of copper metal catalysts for methanol decomposition, methanol steam reforming and methanol synthesis. Top. Catal. 2003, 22, 191-203, doi:10.1023/a:1023567718303. [CrossRef]

166. Breen, J.P.; Ross, J.R.H. Methanol reforming for fuel-cell applications: development of zirconia-containing $\mathrm{Cu}-\mathrm{Zn}-\mathrm{Al}$ catalysts. Catal. Today 1999, 51, 521-533. [CrossRef]

167. Valdés-Solís, T.; Marbán, G.; Fuertes, A.B. Nanosized catalysts for the production of hydrogen by methanol steam reforming. Catal. Today 2006, 116, 354-360. [CrossRef]

168. Agarwal, V.; Patel, S.; Pant, K. $\mathrm{H}_{2}$ production by steam reforming of methanol over $\mathrm{Cu} / \mathrm{ZnO} / \mathrm{Al}_{2} \mathrm{O}_{3}$ catalysts: transient deactivation kinetics modeling. Appl. Catal. Gen. 2005, 279, 155-164.10.1016/J.APCATA.2004.10.026. [CrossRef]

169. Cao, W.; Chen, G.; Li, S.; Quan, Y. Methanol-steam reforming over a $\mathrm{ZnO}-\mathrm{Cr}_{2} \mathrm{O}_{3} / \mathrm{CeO}_{2}-\mathrm{ZrO}_{2} / \mathrm{Al}_{2} \mathrm{O}_{3}$ catalyst. Chem. Eng. J. 2006, 119, 93-98. [CrossRef]

170. tsang Lee, M.; Greif, R.; Grigoropoulos, C.P.; Park, H.G.; Hsu, F.K. Transport in packed-bed and wall-coated steam-methanol reformers. J. Power Sour. 2007, 166, 194-201, doi:10.1016/j.jpowsour.2007.01.007. [CrossRef]

171. Saidi, M. Performance assessment and evaluation of catalytic membrane reactor for pure hydrogen production via steam reforming of methanol. Int. J. Hydrog. Energy 2017, 42, 16170-16185, doi:10.1016/j.ijhydene.2017.05.130. [CrossRef]

172. Mobile Hybrid Power shows APU with Serenergy HTPEM. Fuel Cells Bull. 2013, 2013, 8. [CrossRef]

173. Arsalis, A.; Nielsen, M.P.; Kær, S.K. Modeling and off-design performance of a 1kWe HT-PEMFC (high temperature-proton exchange membrane fuel cell)-based residential micro-CHP (combined-heat-and-power) system for Danish single-family households. Energy 2011, 36, 993-1002, doi:10.1016/j.energy.2010.12.009. [CrossRef]

174. Liu, Y.; Lehnert, W.; Janßen, H.; Samsun, R.C.; Stolten, D. A review of high-temperature polymer electrolyte membrane fuel-cell (HT-PEMFC)-based auxiliary power units for diesel-powered road vehicles. J. Power Sour. 2016, 311, 91-102, doi:10.1016/j.jpowsour.2016.02.033. [CrossRef]

175. First methanol filling station opens to serve range-extender cars. Fuel Cells Bull. 2015, 2015, 7-8, doi:10.1016/S1464-2859(15)30254-6. [CrossRef] 
176. Blue World Technologies signs strategic cooperation agreement with Chinese electric vehicle manufacturer AIWAYS - Blue World Technologies. Available online: https:/ / www.blue.world/blue-world-technologiessigns-strategic-cooperation-agreement-with-chinese-electric-vehicle-manufacturer-aiways / (accessed on 10 December 2019).

177. Millo, F.; Caputo, S.; Piu, A. Analysis of a HT-PEMFC range extender for a light duty full electric vehicle (LD-FEV). Int. J. Hydrog. Energy 2016, 41, 16489-16498, doi:10.1016/j.ijhydene.2016.04.120. [CrossRef]

178. Blue World Technologies. Available online: https://www.blue.world (accessed on 10 December 2019).

179. Gas Fuelled Ships onboard Fuel Cell powered Viking Mariella. Available online: https://www. motorship.com/gfsconference/latest-news101/unique-venue-revealed-another-first-for-gfs!2 (accessed on 10 December 2019)

180. Serenergy. The first methanol fuel cell powered vessel in Germany is now sailing the waters of lake Baldeneysee. Available online: https://serenergy.com/the-first-methanol-fuel-cell-powered-vessel-ingermany-is-now-sailing-the-waters-of-lake-baldeneysee/ (accessed on 10 December 2019)

181. ZBT, Helbio, Advent demo HTPEM stack in CHP configuration. Fuel Cells Bull. 2013, 2013, 11, doi:10.1016/S1464-2859(13)70114-7. [CrossRef]

182. Nielsen, E.R.; Prag, C.B.; Bachmann, T.M.; Carnicelli, F.; Boyd, E.; Walker, I.; Ruf, L.; Stephens, A. Status on Demonstration of Fuel Cell Based Micro-CHP Units in Europe. Fuel Cells 2019, 19, 340-345, doi:10.1002/fuce.201800189. [CrossRef]

183. Elcore to Install 135 Micro-CHP Fuel Cells in Europe under ene.field Project. Available online: http:/ / www.fuelcelltoday.com/news-archive/2013/august/elcore-to-install-135-micro-chp-fuelcells-in-europe-under-enefield-project (accessed on 10 December 2019).

184. Oh, M.H.; Yoon, Y.S.; Park, S.G. The electrical and physical properties of alternative material bipolar plate for PEM fuel cell system. Electrochim. Acta 2004, 50, 777-780. [CrossRef]

185. Ribeirinha, P.; Boaventura, M.; Lopes, J.C.B.; Sousa, J.M.; Mendes, A. Study of different designs of methanol steam reformers: Experiment and modeling. Int. J. Hydrog. Energy 2014, 39, 19970-19981. doi:10.1016/j.ijhydene.2014.10.029. [CrossRef]

186. Pan, C.; He, R.; Li, Q.; Jensen, J.O.; Bjerrum, N.J.; Hjulmand, H.A.; Jensen, A.B. Integration of high temperature PEM fuel cells with a methanol reformer. J. Power Sour. 2005, 145, 392-398, doi:10.1016/j.jpowsour.2005.02.056. [CrossRef]

187. Ji, F.; Yang, L.; Li, Y.; Sun, H.; Sun, G. Performance enhancement by optimizing the reformer for an internal reforming methanol fuel cell. Energy Sci. Eng. 2019, 1-11, doi:10.1002/ese3.461. [CrossRef]

188. Agency for toxic substances and disease registry (ATSDR). Medical Management Guidelines (MMGs): Formaldehyde. Available online: https:/ / www.atsdr.cdc.gov/mmg/mmg.asp (accessed on 25 January 2020)

189. Rihko-Struckmann, L.K.; Peschel, A.; Hanke-Rauschenbach, R.; Sundmacher, K. Assessment of Methanol Synthesis Utilizing Exhaust $\mathrm{CO}_{2}$ for Chemical Storage of Electrical Energy. Ind. Eng. Chem. Res. 2010, 49, 11073-11078, doi:10.1021/ie100508w. [CrossRef]

190. Ursúa, A.; Barrios, E.L.; Pascual, J.; Martín, I.S.; Sanchis, P. Integration of commercial alkaline water electrolysers with renewable energies: Limitations and improvements. Int. J. Hydrog. Energy 2016, 41, 12852-12861, doi:10.1016/j.ijhydene.2016.06.071. [CrossRef]

191. Koponen, J.; Kosonen, A.; Ruuskanen, V.; Huoman, K.; Niemelä, M.; Ahola, J. Control and energy efficiency of PEM water electrolyzers in renewable energy systems. Int. J. Hydrog. Energy 2017, 42, 29648-29660, doi:10.1016/j.ijhydene.2017.10.056. [CrossRef]

192. Bertuccioli, L.; Chan, A.; Hart, D.; Lehner, F.; Madden, B.; Standen, E. Study on Development of Water Electrolysis in the EU; Technical report; E4tech Sàrl: Lausanne, Switzerland, 2014.

193. Sdanghi, G.; Maranzana, G.; Celzard, A.; Fierro, V. Review of the current technologies and performances of hydrogen compression for stationary and automotive applications. Renew. Sustain. Energy Rev. 2019, 102, 150-170, doi:10.1016/j.rser.2018.11.028. [CrossRef]

194. DOE. DOE Technical Targets for Fuel Cell Systems and Stacks for Transportation Applications. Available online: https://www.energy.gov/eere/fuelcells/doe-technical-targets-fuel-cell-systems-andstacks-transportation-applications (accessed on 10 December 2019).

195. Konda, N.M.; Shah, N.; Brandon, N.P. Optimal transition towards a large-scale hydrogen infrastructure for the transport sector: The case for the Netherlands. Int. J. Hydrog. Energy 2011, 36, 4619-4635, doi:10.1016/j.ijhydene.2011.01.104. [CrossRef] 
196. Fornero, E.L.; Chiavassa, D.L.; Bonivardi, A.L.; Baltanás, M.A. $\mathrm{CO}_{2}$ capture via catalytic hydrogenation to methanol: Thermodynamic limit vs. 'kinetic limit'. Catal. Today 2011, 172, 158-165, doi:10.1016/j.cattod.2011.02.036. [CrossRef]

197. Clausen, L.R.; Houbak, N.; Elmegaard, B. Technoeconomic analysis of a methanol plant based on gasification of biomass and electrolysis of water. Energy 2010, 35, 2338-2347, doi:10.1016/j.energy.2010.02.034. [CrossRef]

198. Dagdougui, H.; Sacile, R.; Bersani, C.; Ouammi, A. Chapter 4-Hydrogen Storage and Distribution: Implementation Scenarios. In Hydrogen Infrastructure for Energy Applications; Dagdougui, H., Sacile, R., Bersani, C., Ouammi, A., Eds.; Academic Press: Cambridge, MA, USA, 2018; pp. 37-52, doi:10.1016/B978-0-12-812036-1.00004-4. [CrossRef]

199. Hansson, J.; Hackl, R.; Taljegard, M.; Brynolf, S.; Grahn, M. The potential for electrofuels production in Sweden utilizing fossil and biogenic $\mathrm{CO}_{2}$ point sources. Front. Energy Res. 2017, 5, doi:10.3389/fenrg.2017.00004. [CrossRef]

200. Lindsey, R. Climate Change: Atmospheric Carbon Dioxide. Available online: https://www.climate. gov/news-features/understanding-climate/climate-change-atmospheric-carbon-dioxide (accessed on 10 December 2019).

201. Keith, D.W.; Holmes, G.; St. Angelo, D.; Heidel, K. A Process for Capturing $\mathrm{CO}_{2}$ from the Atmosphere. Joule 2018, 2, 1573-1594, doi:10.1016/j.joule.2018.05.006. [CrossRef]

202. Demir, M.E.; Dincer, I. Cost assessment and evaluation of various hydrogen delivery scenarios. Int. J. Hydrog. Energy 2018, 43, 10420-10430, doi:10.1016/j.ijhydene.2017.08.002. [CrossRef]

203. Ogden, J.M.; Steinbugler, M.M.; Kreutz, T.G. A comparison of hydrogen, methanol and gasoline as fuels for fuel cell vehicles: implications for vehicle design and infrastructure development. J. Power Sour. 1999, 79, 143-168, doi:10.1016/S0378-7753(99)00057-9. [CrossRef]

204. Dolan, G. Methanol: Renewable Hydrogen Carrier Fuel; Technical report; Methanol Institute: Alexandria, VA, USA, 2019.

205. Schreffler, R. Costs Check Growth of Fuel-Cell Infrastructure. Available online: https:/ /www.wardsauto. com/technology/ costs-check-growth-fuel-cell-infrastructure (accessed on 10 December 2019).

(C) 2020 by the authors. Licensee MDPI, Basel, Switzerland. This article is an open access article distributed under the terms and conditions of the Creative Commons Attribution (CC BY) license (http:/ / creativecommons.org/licenses/by/4.0/). 